NBER WORKING PAPER SERIES

\title{
THE GENDERED IMPACT OF THE COVID-19 RECESSION ON THE US LABOR MARKET
}

\author{
Stefania Albanesi \\ Jiyeon Kim
}

Working Paper 28505

http://www.nber.org/papers/w28505

\author{
NATIONAL BUREAU OF ECONOMIC RESEARCH \\ 1050 Massachusetts Avenue \\ Cambridge, MA 02138 \\ February 2021
}

We are grateful to Nicholas Fleming for excellent research assistance. The views expressed herein are those of the authors and do not necessarily reflect the views of the National Bureau of Economic Research.

NBER working papers are circulated for discussion and comment purposes. They have not been peer-reviewed or been subject to the review by the NBER Board of Directors that accompanies official NBER publications.

(C) 2021 by Stefania Albanesi and Jiyeon Kim. All rights reserved. Short sections of text, not to exceed two paragraphs, may be quoted without explicit permission provided that full credit, including $(\odot$ notice, is given to the source. 
The Gendered Impact of the COVID-19 Recession on the US Labor Market

Stefania Albanesi and Jiyeon Kim

NBER Working Paper No. 28505

February 2021

JEL No. E24,J16,J2,J21,J23

\begin{abstract}
$\underline{\text { ABSTRACT }}$
The economic crisis associated with the emergence of the novel corona virus is unlike standard recessions. Demand for workers in high contact and inflexible service occupations has declined, while parental supply of labor has been reduced by lack of access to reliable child care and inperson schooling options. This has led to a substantial and persistent drop in employment and labor force participation for women, who are typically less affected by recessions than men. We examine real time data on employment, unemployment, labor force participation and gross job flows to document the gendered impact of the pandemic. We also discuss the potential long-term implications of this crisis, including the role of automation in depressing the recovery of employment for the worst hit service occupations.
\end{abstract}

Stefania Albanesi

Department of Economics

University of Pittsburgh

4901 Wesley W. Posvar Hall

Pittsburgh, PA 15260

and CEPR

and also NBER

stefania.albanesi@gmail.com

Jiyeon Kim

263(Bangok-dong, Korea Development Institute)

Namsejong-ro

Sejong-si 30149

Korea

jik51@kdi.re.kr 


\section{Introduction}

Recessions in the United States are usually associated with a larger employment drop for men than for women (Doepke and Tertilt (2016) and Albanesi (2019)). This asymmetry is partly explained by gender differences in the occupation distribution, with men primarily employed in production occupations and women concentrated in service occupations, which tend to be less cyclical Albanesi and Şahin (2018), Olsson (2019)). Additionally, married women tend to increase their attachment to the labor force during economic downturns relative to expansions, as a form of household insurance that reduces the adverse impact of recessions (Ellieroth (2019)). The lower cyclicality of women's employment has determined a reduction in the cyclical volatility of aggregate employment, as the share of women in the workforce increased from the 1970s onward (Albanesi (2019)).

The recession resulting from the emergence of COVID-19 sharply differs from typical recessions. First, there has been a sizable drop in the demand for services, as a result of both the mitigation measures enacted to contain the pandemic and consumers' response to the risk of infection (Chetty et al. (2020)). Given the concentration of women in service occupations, they have been disproportionately hit by the corresponding employment losses. Second, limited availability of in-person childcare and schooling options have led many mothers to exit the labor force. Thus, both demand and supply of female employment have been adversely affected during the pandemic, removing an important source of household insurance and an automatic stabilizer for the aggregate labor market (Albanesi et al. (2020), Alon et al. (2020b)).

To highlight the unprecedented behavior of the labor market during the pandemic, we first briefly review the historical evidence on the cyclicality of employment by gender. We then examine real time data on the impact of the coronavirus pandemic on the labor market. First, we classify occupations by their exposure to the pandemic, based on contact intensity and ability to work remotely. We show that women are overrepresented in high-contact and inflexible occupations most affected by the pandemic. While these occupations account for $15 \%$ of total employment, $73 \%$ of workers employed in these jobs are women. Employment in these occupations dropped by $40 \%$ from February to April 2020 and, by the end of the year, was still 10 percentage points below pre-pandemic values. We then examine the behavior of employment, unemployment and non-participation during the pandemic, and the role of the occupation distribution in accounting for gender differences in the response. We find that, controlling for age and education, employment was on average 5.3 percentage points lower in the spring (March to May) and the summer (June to August) relative to February 2020, and 3 percentage points lower in the fall (September to December). Employment fell more for women compared to men at every stage of the pandemic, with the biggest gender differences estimated for married women with children, whose employment fell by an additional 4 percentage points compared to men in that category in the spring and summer. Controlling for occupation attenuates the decline in employment and the gender differences by about one third. Overall, women's employment losses account for $66 \%$ of the aggregate decline in employ- 
ment in the spring, $63 \%$ in the summer and $59 \%$ in the fall of 2020, though their pre-pandemic share of the population was $52 \%$. A very similar pattern holds for unemployment, suggesting that the occupational distribution accounts only for a small fraction of the incremental employment losses suffered by women during the pandemic. Non-participation rises by approximately one third of a percentage point during the pandemic compared to February 2020 and controlling for occupation reduces this effect to 0.1 percentage points. The gender gap is largest for this variable with women's share of the rise in non-participation accounting for $70 \%$ of the aggregate in the spring, $86 \%$ of the average in the summer, and over 100 percent of the average in the fall, as male non-participation declines while women's non-participation continues to be higher than in February 2020. Women with children show the largest gaps in the increase in non-participation compared to men in the same category, though controlling for occupation, attenuates the gap for single women. Even controlling for occupation, married women with children experience a rise in non-participation that is approximately 0.5 percentage points larger than married men for the summer and fall.

To isolate labor demand and labor supply factors, we also examine the behavior of gross job flows. We find sizable and significant gender gaps in the response of employment to unemployment (EU) flows and employment to non-participation (EN) flows. Controlling for age and education, EU rise more than twice as much for women compared to men in the spring and summer. Even with occupation controls, sizable gender gaps remain in the spring for single parents and married workers. Turning to EN, which more than doubles during the pandemic, we find sizable gender gaps pointing to a greater rise for women. These remain after controlling for occupation for single parents in the spring and summer and for married parents in summer. To interpret our findings for 2020, we use a similar approach to examine the behavior of employment, non-participation, EU and EN flows during the great recession. We show that the pattern of gender differences were completely reversed relative to the 2020 recession. Women's employment fell by substantially less than men's and their non-participation rose by less, with differences in the occupational distribution accounting for all the gender gaps for married workers.

We conclude by discussing some of the continuing impacts of the pandemic. Given its disproportionate impact on women's employment and participation, and the link between gender wage gaps and non-participation spells for women, one possible implication of the 2020 recession is a rise in gender wage gaps. Adda, Dustmann, and Stevens (2017) estimate that $13 \%$ of the gender wage gap can be explained by spells of non-participation, which are associated with human capital depreciation and skill obsolescence. We also consider the prospect for a full recovery of aggregate employment. Our point of departure is that since the 1990 recession the United States has experienced "jobless recoveries," that is cyclical rebounds in economic activity where labor market performance did not keep pace with GDP growth and aggregate demand recovery. One possible explanation of this phenomenon is that the job losses associated with structural change, such as the trend decline in manufacturing, and technological advancements leading to the emergence of labor saving technologies, such as automation, are concentrated in recessions and they are not reversed 
as the economy recovers (Groshen and Potter (2003), Jaimovich and Siu (2020)). This scenario is plausible for the pandemic recession, even more so as the risk of infection is expected to persist for several years, which may generate additional incentives to adopt labor saving technologies in order to limit the costs associated with adapting workplaces and practices to this new reality. To explore this possibility, we consider susceptibility to automation by occupation, using an index created by Autor and Dorn (2013) as well as our own measure. We find that about half of the inflexible/highcontact occupations that have experienced the biggest declines in employment during the pandemic have high susceptibility to automation.

The paper is structured as follows. Section 2 reviews the evidence on cyclicality of employment by gender. Section 3 introduces our occupational classification and documents the distribution of occupation by gender and exposure to COVID-19. Section 4 examines real time data on the impact of the pandemic recession on employment, unemployment, non-participation and gross job flows for men and women, and compares it to the great recession. Section 5 discusses the continuing impacts.

\section{Employment by Gender in Typical Recessions}

We briefly review the evidence on the cyclicality of employment by gender in typical recessions. We use yearly data from the Current Population Survey (CPS) between 1976 and 2019. The sample includes workers of age from 25 to 54, armed force excluded. We focus on the employment to population ratio by gender, marital status and by presence of children younger than 12 years old. Let $y_{t}^{C}$ denote the cyclical component of the logarithm of real GDP per capita in year $t$, and $e_{t}^{i, C}$ the cyclical component of the logarithm of the employment to population ratio for group $i$, where the groups vary by gender, marital status and the presence of children. The cyclical components are extracted with a Hodrick-Prescott filter with smoothing parameter $\lambda=6.5$ (Ravn and Uhlig $(2002))$. We estimate:

$$
e_{t}^{i, C}=\beta y_{t}^{C}+\epsilon_{t}
$$

and then compute the standard deviation of $\hat{e}_{t}^{i, C}=\hat{\beta} y_{t}^{C}$ over the sample period and take its ratio to the standard deviation of $y_{t}^{C}$. The variable $\hat{e}_{t}^{i, C}$ captures the component of employment to population ratio for group $i$ that is associated to cyclical variations in GDP, and its standard deviation is a measure of the cyclicality of this variable. The results are reported in Table 1 .

Table 1: Business Cycle Volatility by Gender, Marital Status and Presence of Children

\begin{tabular}{|l|c|c|c|c|c|c|c|}
\hline \hline & All & Married & Single & Married w/o Children & Single w/o Children & Married with Children & Single with Children \\
\hline Men & 0.66 & 0.51 & 1.04 & 0.61 & 1.18 & 0.66 & 1.74 \\
Women & 0.46 & 0.42 & 0.52 & 0.34 & 0.48 & 0.45 & 0.99 \\
\hline \hline
\end{tabular}

Standard deviation of cyclical component of the employment to population ratio by gender and marital status, as estimated from equation 1. Yearly data for 1976-2019, HP filtered with parameter $\lambda=6.5$. Source: Authors' calculations based on the CPS. 
Consistent with Doepke and Tertilt (2016) and Albanesi (2019), we find that female employment is less cyclical than male employment. The standard deviation of the cyclical component of the employment to population ratio is $66 \%$ of the standard deviation of GDP for men and $46 \%$ for women. The differences are larger for single individuals than for married, with the standard deviation for married men equal to $51 \%$ of the standard deviation of GDP and the standard deviation of married women equal to $42 \%$, while the corresponding values for single men and women are respectively $104 \%$ and $52 \%$. The differences in cyclicality by marital status likely stems from differences in age and educational attainment, as single individuals are more likely to be young and less skilled, and these categories of workers are more business cycle sensitive (Mincer (1991), Shimer (1998)). We also consider how exposure to business cycles varies with the presence of children of age less than 12 years old. We find that both for single and married individuals, those without children display lower cyclicality than those with children, and that gender gaps in cyclicality are smallest for individuals with children compared to those without, conditional on marital status. Individuals married without children display the lowest cyclicality, with the standard deviation of their employment to population ratio equal to $61 \%$ of the standard deviation of GDP for men and $34 \%$ for women in this group. At the other extreme, single individuals with children display the highest cyclical volatility in employment, with the standard deviation of their employment to population ratio equal to $174 \%$ of the standard deviation of GDP for men, and $99 \%$ for women. Single parents are the demographic group most exposed to standard business cycle risk. Single fathers's exposure is 3 times as large as for married fathers, while single mothers' exposure is twice as large as for married mothers. Again, this difference may be related to differences in educational attainment across single and married parents (Taylor (2010)).

There are two main factors that account for the lower cyclicality of female employment. The first is occupation and industry distribution and the second the cyclical properties of labor supply. Albanesi and Şahin (2018) show that women are more likely to be employed in service providing industries and service occupations, which tend to be less cyclical compared to goods producing industries and production occupations that employ a larger share of men. They show that this accounts for most of the difference in the loss in employment during recessions since 1990. The occupation and industry distribution by gender does not vary by marital status (Cortes and Pan (2018)) and can explain why both for single and married workers employment is less cyclical for women.

The second factor leading to lower cyclicality of female employment applies exclusively to married individuals, and is related to household insurance via labor supply, also known as the "added worker effect." Since the first study isolating this mechanism Lundberg (1985), a variety of contributions have confirmed the importance of this channel. Cullen and Gruber (2000) show that unemployment insurance benefits crowd out the spousal increase in labor supply associated with a spell of unemployment, Stephens (2002) estimates the added worker effect in response to job displacement. Parker and Skoufias (2004) examine data from Mexico and find that there is a sizable 
added worker effect in economic downturns, Juhn and Potter (2007) examine the evolution over time of the added worker effect in the United States. Shore (2010) examines the risk sharing of marriage over the business cycle and finds that husbands' and wives' incomes are less positively correlated in recessions. Additionally, in cohorts of couples who had been married through relatively bad times, high-earning husbands tend to be married to low-earning wives and vice versa, with a large and statistically significant effect. Blundell, Pistaferri, and Saporta-Eksten (2016) examine the link between wage and consumption inequality using a structurally estimated life-cycle model incorporating consumption and family labor supply decisions, and find a sizable role for household insurance via wives' labor supply.

Albanesi (2019) shows that this channel renders women's labor supply countercyclical, and Ellieroth (2019) specifically shows that married women are less likely to leave the labor force and are more attached to employment in recessions. She shows that this form of precautionary labor supply in response to the higher threat of job loss experienced by their husband in recessions accounts for $30 \%$ of married women's low cyclicality of employment 1

The impact of children on married women's labor supply over the business cycle has not so far been studied by this literature, but the lower cyclicality of employment for both single and married workers without children compared to those with children may reflect lower ability to adjust labor supply in response to business cycle variation on part of married individuals of both genders.

\section{Exposure to the COVID-19 Recession by Occupation}

To determine exposure to the COVID-19 recession, we classify occupations along two dimensions based on their flexibility and contact intensity. The distinction between flexible and inflexible occupations is made according to whether the occupation can be carried out remotely. Flexible occupations include occupations that allow their employees to work remotely, whereas inflexible occupations involve outdoor activities or require operating on site equipment. The distinction between high-contact and low-contact occupations is based on workers' physical proximity to customers or co-workers while on the job. We then document the distribution by gender across these occupations.

We create the measures of flexibility and contact intensity using data from the Occupational Information Network (O*NET). The O*NET survey started in 1998 and updated on an irregular basis. We use the most recent version published in February 2020. O*NET asks a random sample

\footnotetext{
${ }^{1} \mathrm{~A}$ number of recent papers develop quantitative models capturing the implications for consumption smoothing and welfare. See Park et al. (2020) show that wives increase their labor supply significantly in response to increases in the variance of husbands' permanent wage shocks, reducing the welfare cost of increased earnings risk since the early 1970s. Ortigueira and Siassi (2013) examine the role of the family as a risk sharing institution in an economy with idiosyncratic labor income and unemployment risk. Mankart and Oikonomou (2017) build a theory of joint household search in a frictional labor market to argue that the acyclicality of the labor force is due to the added worker effect. Wu and Krueger (2021) calibrated life-cycle two-earner household model with endogenous labor supply can rationalize the extent of consumption insurance against shocks to male and female wages.
} 
of U.S. workers in each occupation various questions about typical work activities required in their occupations. To measure occupations' flexibility, we consider fifteen questions, reported in the Online Appendix, designed to elicit whether workers are performing tasks that can be executed remotely, or whether they are bound to their work location by the need to operate or inspect equipment. Respondents answer each question on an ordinal scale of one to five, and we take the average across respondents' answers. To compute the contact intensity measure, we use a question asking about physical proximity to other people while working. Again, respondents answer on an ordinal scale of one to five with each number assigned with a specific example describing the distance to other people. The Online Appendix presents the measures of flexibility and contact intensity by occupations' major groups.

We classify occupations as inflexible if their inflexibility score is above the median and as flexible otherwise. Similarly, we consider the occupation to be high-contact occupation if an average respondent says that she works at arm's length or closer to other people, which is closer than safe social distancing distance of 6 feet. Based on these two criteria, we aggregate occupation groups into four categories: flexible and high-contact, flexible and low-contact, inflexible and high-contact, or inflexible and low-contact. This grouping is reported in Table $2^{2}$ Flexible/high-contact occupation comprise mainly education jobs, while flexible/low-contact occupations comprise managerial and professional occupations. Inflexible/high-contact occupations are dominated by healthcare and services, both personal and hospitality. Finally, the inflexible/low-contact category comprises most production, protection and transportation occupations, as well as construction and farming.

Table 2: Occupation Classification

\begin{tabular}{lll}
\hline \multicolumn{1}{c}{ Flexible } & \multicolumn{1}{c}{ Inflexible } \\
\hline High-contact & Education, Training, and Library & $\begin{array}{l}\text { Healthcare Practitioners and Technical } \\
\text { Healthcare Support } \\
\text { Food Preparation and Serving } \\
\text { Personal Care and Service }\end{array}$ \\
& & \\
\hline Low-contact & Management & Protective Service \\
& Business & Building and Grounds Cleaning and Maintenance \\
& Computer and Mathematical & Farming, Fishing, and Forestry \\
& Architecture and Engineering & Construction Trades, Extraction \\
& Life, Physical, and Social Science & Installation, Maintenance, and Repair \\
& Legal & Production \\
& Arts, Design, Entertainment, Sports, and Media & \\
Sales and Related & \\
& Office and Administrative & \\
\hline
\end{tabular}

Author's calculations based on O*NET. Occupations are inflexible if their inflexibility score is above the median and flexible otherwise. Occupations are high-contact if the contact intensity score corresponds to a distance of less than 6 feet. Flexibility scores and contact intensity scores are reported in Table 8 in the Online Appendix.

Figure 2 plots the log variation in the employment to population ratio relative to one year prior in 2020 for the four occupational categories. We report the variation relative to one year

${ }^{2}$ Dingel and Neiman (2020) ) classify occupations based on the ability of working remotely. ?) also consider how workers in different occupations are affected by social distancing policies. 
prior to account for seasonality in employment variation by occupation 3 Inflexible/high-contact occupations show the largest decline in employment, reaching a trough of $-38 \%$ in April, and only recovering to $-12 \%$ by September, with further declines by the end of the year. Inflexible/lowcontact occupations are the second worst hit, with a decline in employment of close to $30 \%$ in April, though employment for these occupations is only $5 \%$ lower than one year prior by the fall. Employment in flexible/high-contact occupations dropped to a low of $-17 \%$ relative to one year prior in April but recovered rapidly, and has remained 2-8\% lower than one year prior in the summer and fall. Finally, flexible/low-contact occupations were the least impacted, with a drop in employment of $-9 \%$ relative to one year prior in April, and a recovery to $2-4 \%$ lower relative to one year prior from June onward. Inflexible/high-contact and inflexible/low-contact occupations comprise most workers deemed essential, even if this designation varies by state (Blau, Koebe, and Meyerhofer $(2020))$. Yet, these two categories experience the biggest decline in employment.

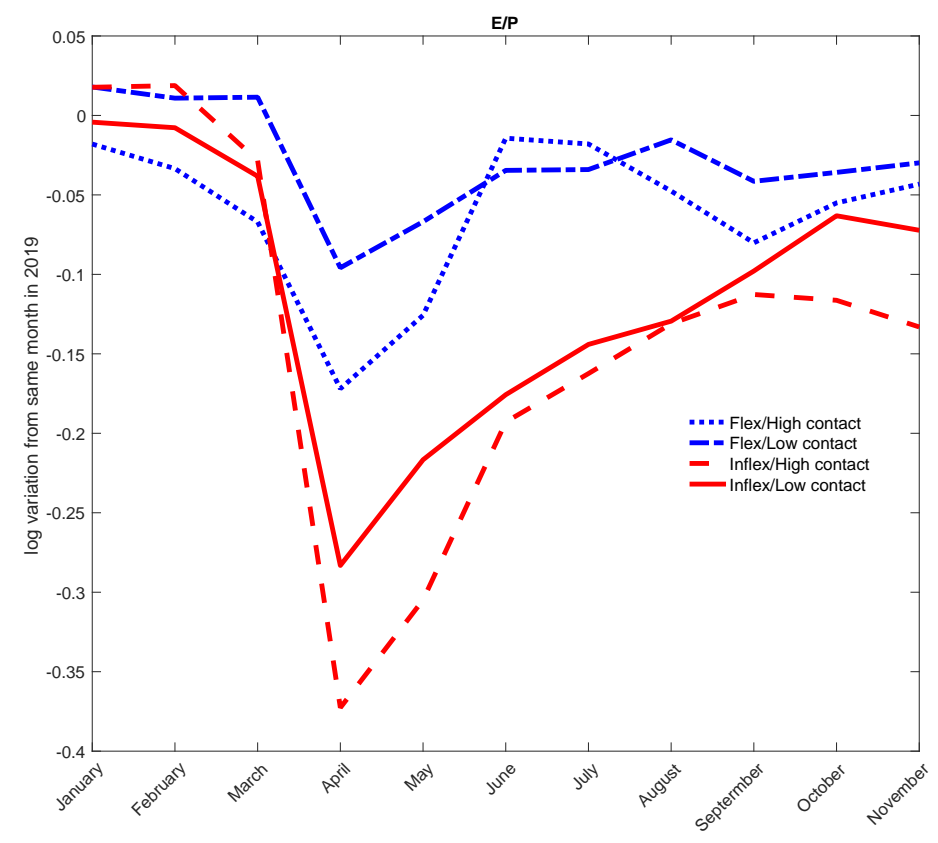

Figure 1: Log variation in E/P from from one year prior by occupation. Source: Authors' calculations based on the CPS.

Table 3 reports the distribution of workers by gender across occupations for four categories defined in Table2. The inflexible/high-contact occupations are the most vulnerable to the COVID-19 shock and are dominated by female workers. We find that $23 \%$ of female workers are employed in occupations that are inflexible/high-contact, while only $7 \%$ of men work in these occupations, corresponding to a female share of employment in these occupations of $73 \%$. Flexible/high-contact occupations also exhibit a high female share at $74 \%$. Male workers are disproportionately rep-

\footnotetext{
${ }^{3}$ Flexible/high-contact occupations, which primarily include teaching occupations, are the only category displaying seasonable variation. Results are very similar for all categories to considering log variations from February 2020.
} 
resented in inflexible, low-contact occupations, with $39 \%$ of male workers but only $9 \%$ of female workers are employed in these occupations, with a female share of employment of only $17 \%$ in this category. Flexible/low-contact occupations are the largest category, accounting for $53 \%$ of overall employment, specifically $57 \%$ of female employment and $50 \%$ of male employment, with a female share of $49 \%$.

Table 3: Occupational Distribution by Gender

\begin{tabular}{lcccc}
\hline Group & Employed women (\%) & Employed men (\%) & Total employed (\%) & Female share (\%) \\
\hline Flexible, High-contact & 10 & 3 & 7 & 74 \\
\hline Flexible, Low-contact & 57 & 50 & 53 & 49 \\
\hline Inflexible, High-contact & 23 & 7 & 15 & 73 \\
\hline Inflexible, Low-contact & 9 & 39 & 25 & 17 \\
\hline \hline Data Source: Basic montly CPS, Feb 2020
\end{tabular}

Figure 2 displays the $\log$ variation in the employment to population ratio by occupation and gender. For flexible/low-contact occupations, which account for the biggest share of employment, the drop in employment in the spring was similar for men and women, though female employment remained approximately 1 percentage point lower in the summer and fall compared to men. For flexible/high-contact occupations, employment for women fell by approximately 5 percentage points more in April and in the fall compared to men, though the drop in employment for women was smaller than for men in the summer. For the inflexible occupational categories, there are some notable differences. For inflexible/high-contact occupations, men's employment fell by 8 percentage points more in April compared to women. Though it recovered to approximately $18 \%$ lower relative to one year prior by July, it stayed at that level or lower through the fall. By contrast for women, employment was only $13 \%$ lower relative to one year prior by August, and it has remained mostly stable through the fall. For inflexible/low-contact occupations the pattern is reversed. Women's employment dropped to $42 \%$ relative to one year prior in April and only $25 \%$ for men. Men's employment recovered slowly but steadily, reaching a level $10 \%$ lower than 1 year prior by September. Women's employment also eventually recovered to that level, though there was a period of further reduction in early fall.

Two patterns emerge from these results. First, for flexible/low-contact occupations, the recovery in employment was smaller for women. Though the difference by gender is small, it is still notable as this category accounts for the largest share of female employment, and therefore affects a large segment of the female workforce. The second pattern is that in inflexible occupations, workers with the lowest representation by gender lost more jobs. This may be due to negative selection of male workers into female dominated inflexible/high-contact occupations and of female workers into the male dominated inflexible/low-contact occupations. Additionally, essential frontline workers are concentrated in inflexible/low-contact occupations and since, as documented in Blau, Koebe, and Meyerhofer (2020), they are more likely to be men, this may contribute to the greater decline of employment for women in this category. 

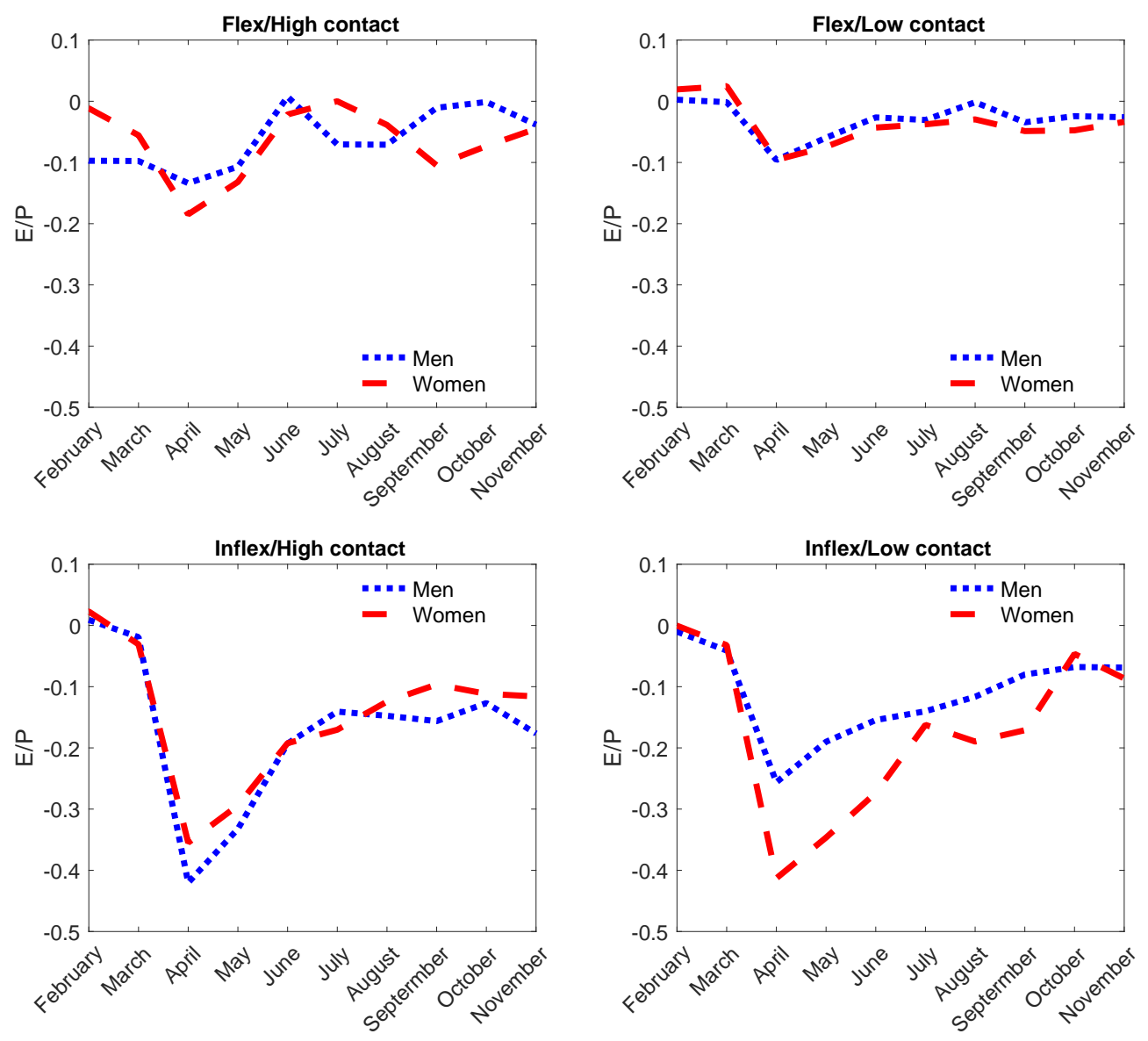

Figure 2: Log variation in E/P from from one year prior in 2020. Source: CPS

The Online Appendix documents the cyclical behavior of employment for the occupational categories we define by gender and marital status. Flexible/low-contact occupations are the least cyclical for all workers, followed by inflexible/high-contact occupations, whereas inflexible/lowcontact occupations display the highest cyclicality. Albanesi et al. (2020) show that this variation is driven by differences in the skill distribution, with workers without a college degree disproportionately represented in inflexible/low-contact occupations. Additionally, workers in high-contact occupations tend to be employed in service providing industries, which are less cyclical than goods producing industries. However, within occupations large differences remain by gender and marital status, reflecting the aggregate pattern document in Table 1.

The behavior of employment over the course of the pandemic is driven by a combination of demand and supply factors that likely differ by gender and are influenced by age and education, in addition to the presence of children. To disentangle these effects, we turn to a labor flow approach to employment dynamics and use regressions to control for age and education. 


\section{Labor Market Impact of the Covid-19 Recession}

To examine the dynamics of employment over the course of 2020, we estimate the following regression:

$$
y_{i, t}=\alpha+\sum_{\tau=1}^{3} \beta_{\tau} \times I(\tau)+\gamma I^{i}(f)+\delta I^{i}(m)+\eta I^{i}(c)+\nu X_{t}^{i}+\epsilon_{i, t}
$$

where $i$ indexes an individual, $t \geq 2$ is a month in 2020, $\tau$ is an indicator variable for one of three phases of the pandemic, with $\tau=1$ corresponding to March to May, $\tau=2$ corresponding to June to August and $\tau=3$ corresponding to September to December. The variable $I^{i}(f)$ is a dummy for gender, equal to 1 for female, $I^{i}(m)$ is a dummy for marital status, equal to 1 for married, and $I^{i}(c)$ is a dummy for children under the age of 12 present, equal to 1 if they are, and $X_{t}^{i}$ include a set of controls for age, educational attainment and, in some specifications, occupation, as categorized in Section 3. Additionally, we include a full set of interactions between the phase effects and the gender, marital status and presence of children dummies, and the age, education and occupation controls. The coefficients $\beta_{\tau}$ estimate the effect of each phase of the pandemic on the dependent variable. The coefficients on the interactions estimate the differential impact of the pandemic on individuals by gender, marital status and presence of children in each phase of the pandemic. The estimated value of $\alpha$ will be the average value of the dependent variable for male, single, childless individuals in February 2020.

We consider three main outcomes: employment, unemployment, and non-participation. Additionally, we estimate this specification for employment to unemployment (EU) and unemployment to employment (UE) flows to isolate labor demand, and employment to non-participation (EN), unemployment to non-participation (UN) flows, to isolate labor supply effects.4 The definition of labor market status follows the CPS except that those who report being employed but absent from work for no particular reasons are classified as unemployed. The stock variables are based on the repeated cross-sectional data. To construct the labor status transitions, we utilize the panel structure of the CPS. Additional details are reported in the Online Appendix.

We begin with employment, unemployment and non-participation. Table 4 reports the average change in these variables in each phase of the pandemic relative to February 2020, calculated from the change for each demographic group weighted by the corresponding population shares for February 2020. We report these estimates for the specification with and without occupation controls. We also report the share of the change accounted for by women for each specification. The rest of the table reports the estimated change relative to February 2020 in the three phases for the pandemic for each demographic group, for the specification with occupational controls.

Employment declined on average by $5.3 \%$ in spring, $5.1 \%$ in summer and $2.7 \%$ in the fall without

\footnotetext{
${ }^{4}$ Lee, Park, and Shin (2021) estimate a similar specification focussing only on April 2020 and November 2020 and they do not examine labor flows.
} 
Table 4: Change in Employment, Unemployment, Non-participation by Demographic Groups

\begin{tabular}{|c|c|c|c|c|c|c|c|c|c|}
\hline & \multicolumn{3}{|c|}{ Employment } & \multicolumn{3}{|c|}{ Unemployment } & \multicolumn{3}{|c|}{ Non-participation } \\
\hline Change since February 2020 & Spring & Summer & Fall & Spring & Summer & Fall & Spring & Summer & Fall \\
\hline Average & & & & & & & & & \\
\hline W/o controlling for occupation & -5.3 & -5.1 & -2.7 & 5.0 & 4.8 & 2.4 & 0.3 & 0.3 & 0.2 \\
\hline Share women & 64.3 & 63.97 & 59.3 & 63.74 & 63.21 & 57.7 & 72.7 & 76.42 & 77.61 \\
\hline Controlling for occupation & -3.6 & -3.3 & -2.8 & 3.5 & 3.2 & 2.8 & 0.1 & 0.1 & 0.1 \\
\hline Share women & 65.9 & 63.2 & 59.4 & 65.8 & 62.6 & 56.9 & 69.5 & 85.6 & 179.1 \\
\hline Men & & & & & & & & & \\
\hline Single w/o children & $-3.42^{* * *}$ & $-3.34^{* * *}$ & $-3.17 * * *$ & $3.22^{* * *}$ & $3.22^{* * *}$ & $3.32^{* * *}$ & 0.19 & 0.11 & -0.14 \\
\hline Single with children & -1.93 & $-2.72^{* *}$ & -0.76 & 2.22 & $3.21^{* *}$ & 0.87 & -0.29 & -0.49 & -0.1 \\
\hline Married w/o children & $-1.32^{* *}$ & $-2 * * *$ & $-1.78^{* * *}$ & $1.34^{* *}$ & $1.9^{* * *}$ & $1.76^{* * *}$ & -0.02 & 0.09 & 0.01 \\
\hline Married with children & $-2.47 * * *$ & $-1.82^{* * *}$ & $-2.11 * * *$ & $2.45 * * *$ & $1.88^{* * *}$ & $2.22 * * *$ & 0 & -0.06 & -0.11 \\
\hline Women & & & & & & & & & \\
\hline Single w/o children & $-5.07 * * *$ & $-4.41 * * *$ & $-4.29 * * *$ & $4.84^{* * *}$ & $4.16^{* * *}$ & $3.98^{* * *}$ & 0.23 & 0.24 & $0.3^{*}$ \\
\hline Single with children & $-3.05^{* * *}$ & $-4.09 * * *$ & $-3.33^{* * *}$ & $2.7^{* * *}$ & $3.99^{* * *}$ & $3.15^{* * *}$ & 0.35 & 0.1 & 0.18 \\
\hline Married w/o children & $-3.76^{* * *}$ & $-3.91^{* * *}$ & $-2.61^{* * *}$ & $3.85^{* * *}$ & $3.89^{* * *}$ & $2.62 * * *$ & -0.08 & 0.01 & -0.01 \\
\hline Married with children & $-5.35^{* * *}$ & $-3.79 * * *$ & $-2.73^{* * *}$ & $5.19^{* * *}$ & $3.53^{* * *}$ & $2.42^{* * *}$ & 0.15 & 0.26 & $0.29^{*}$ \\
\hline
\end{tabular}

The table reports selected estimates from specification 2 for employment, unemployment and non-participation. The full set of estimates are reported in the Online Appendix. Phases of the pandemic correspond to March to May for Spring, June to August for Summer, September to December for Fall. The average effect is obtained by summing the contribution of each demographic group, obtained by multiplying the corresponding estimated effect for each phase of the pandemic with the group's population share in February 2020. The average effect is reported for the specification without and with occupational controls. In each case, "Share women" is the sum of all female contributions divided by the average effect for the specification with occupation controls. The effects by demographic groups are reported for the specification with occupational controls. Asterisks denote significance levels, * for $10 \%,{ }^{* *}$ for $5 \%$ and ${ }^{* * *}$ for $1 \%$. Population shares In February 2020 are reported in the Online Appendix. All values in percentage. Source: Authors' calculations based on CPS.

occupation controls, and by $3.6 \%, 3.3 \%$ and $2.8 \%$ controlling for occupations. This suggests that the occupational distribution can account for over a third of the decline in employment in spring and summer. The share of this change accounted by women is similar with and without occupational controls, ranging from 63 to $66 \%$ in the spring and summer and equal to $59 \%$ in the fall, much larger than women's share in the population in February 2020, which was 52\%. Figure 3 , panels (a) and (b) displays the gender differences in the changes in employment in the three phases of the pandemic by demographic group, with and without occupation controls. The figure clearly shows that women in all demographic groups suffer larger losses in employment compared to men at every stage of the pandemic, with the biggest gender differences estimated for married women with children, whose employment falls by an additional 4 percentage points compared to men in that category in the spring and summer. For married women without children, employment falls by 3 percentage points more than for men in that category over the same time period. Among single parents, women's employment falls by 2.5 percentage points more than men's in summer, and among single individuals without children, women's employment losses are 2 percentage points larger than men's in spring and 1 percentage point larger in summer. Controlling for occupations attenuates the gender differences in employment losses by about one third in spring and summer. For fall, controlling for occupation reduces the gender gaps in employment losses for married workers, though 
it magnifies these gaps for single workers. For single women with children there is a significantly larger drop in employment relative to comparable men only in the fall. These estimates suggest that for single mothers and married women, the occupation distribution plays a limited role in accounting for the gender gaps in the drop in employment.

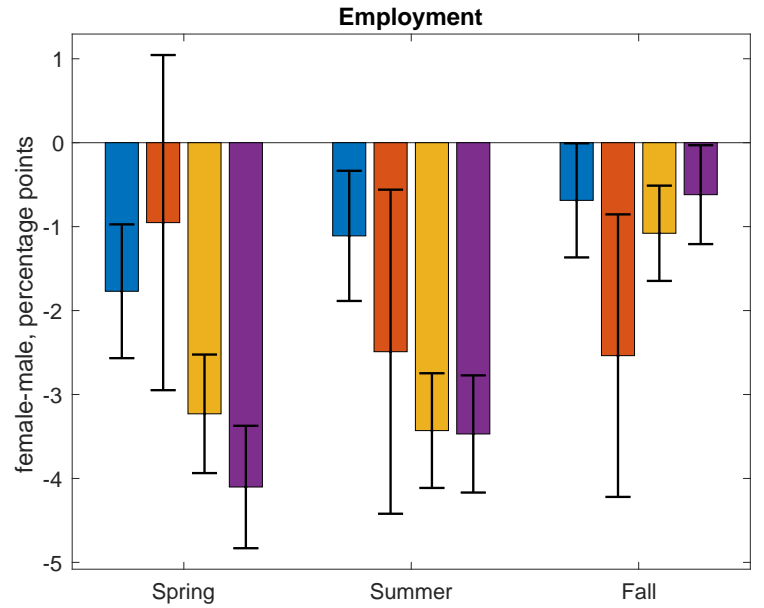

(a) Without occupation controls

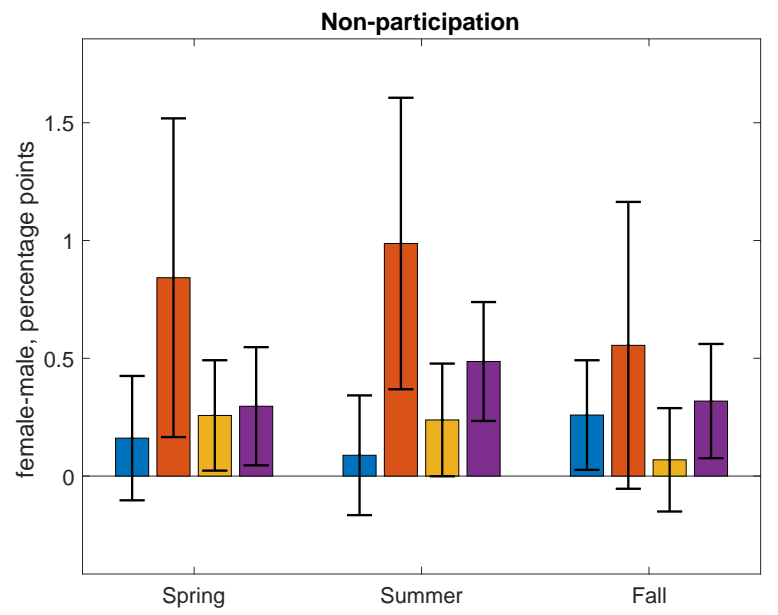

(c) Without occupation controls

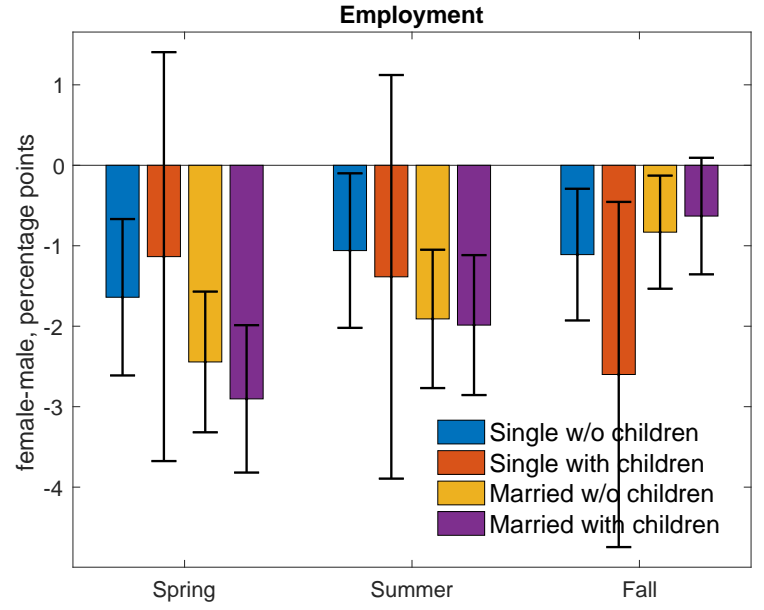

(b) With occupation controls

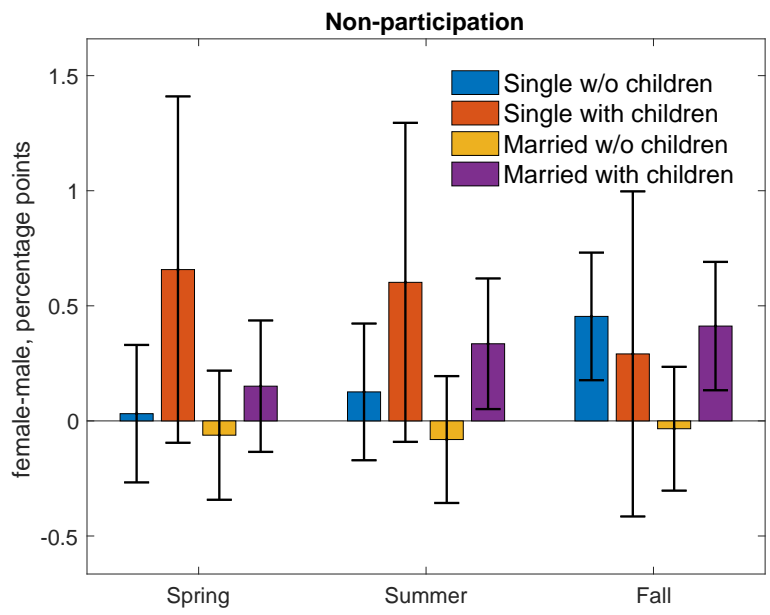

(d) With occupation controls

Figure 3: Female-male difference in changes in employment since February 2020, estimated from equation 2 with and without occupation controls. See note to Table 4 . Error bars denote $90 \%$ confidence intervals. Source: Author's calculations from CPS.

We find a very similar pattern for unemployment, both in terms of the average response, the contribution of occupation controls and for the gender wage gaps by demographic group. Figure 8 in the Online Appendix displays the gender differences in the change in unemployment by demographic group with and without occupation controls.

Turning to non-participation increases on average by 0.3 percentage points in spring and summer 
and by 0.2 percentage points in the fall without controlling for occupation, and by 0.1 percentage points in spring, summer and fall with occupation controls, suggesting that the occupational distribution accounts for one half to two thirds this rise during the pandemic. Without occupation controls, women's share of the rise in non-participation ranges from $73 \%$ in spring to $78 \%$ in the fall. Controlling for occupation, women account for $70 \%$ of the rise in non-participation in the spring, $86 \%$ in the summer and $179 \%$ in the fall, as male non-participation declines over that time period, whereas it rises substantially for women. Figure 3 , panels (c) and (d), displays the gender differences by demographic group for the three phases for the pandemic. Without controlling for occupation, gender differences are particularly large and significant for single parents, among whom women's non-participation rises by nearly 1 percentage point more than men's in the spring and summer. They are also sizable for married parents, among whom women experience a rise in non-participation of approximately 0.5 percentage points more than men in summer and fall. Controlling for occupation reduces the gender gap substantially in the spring and summer, but not in the fall, when single women without children and married women with children show a rise in non-participation that is approximately 0.5 percentage points higher than comparable men. This suggests that the occupation distribution is a more important factor in the response of non-participation for single mothers than it is for married mothers.

To explore the potential role of labor demand and supply factors during the pandemic, we also examine gross labor market flows. To capture the impact of demand factors, we consider the employment to unemployment flow (EU) and the unemployment to employment flow (UE). The EU flow is commonly interpreted as a measure of job destruction and usually rises dramatically at the start of recessions. The UE flow measures the rate at which the unemployed find jobs, and it tends to fall dramatically in recessions and rise during recoveries. To capture the impact of labor supply factors, we consider the employment to non-participation flow (EN) and the unemployment to participation flow (UN). The first captures voluntarily quits, while the second is often interpreted as a key measure of labor market attachment during recessions 5 The estimates of the effect of the pandemic on these flows by demographic group are reported in Table $55^{6}$

We find that EU rises by 3 percentage points in spring, 2 percentage points in summer and 0.5 percentage points in fall, and controlling for occupations lowers these values by a third in the spring and summer, while raises the value for fall to 0.8 . These are large changes, as on average monthly EU flows range between 1.5-2 percentage points for men and 1-1.5 percentage points for

\footnotetext{
${ }^{5}$ See Krusell et al. (2017) for a detailed documentation of the cyclical properties of gross job flows in the United States.

${ }^{6}$ The possibility of classification error is an important concern when analyzing gross job flows. Earlier research has found these errors to be sizable for transitions between unemployment and non-participation. A standard approach to correct this issue is to adjust the gross flows data using Abowd and Zellner (1985) estimates of misclassification probabilities based on resolved labor force status in CPS reinterview surveys, as in Elsby, Hobijn, and Sahin (2015). However, given the short time span of our data and the exceptional nature of the labor markets transitions during the pandemic, it is questionable that those corrections accurately capture the extent of misclassification for our sample. For that reason, we do not apply any adjustment.
} 
Table 5: Change in Labor Flows by Demographic Group

\begin{tabular}{|c|c|c|c|c|c|c|c|c|c|c|c|c|}
\hline & \multicolumn{3}{|c|}{$\overline{\mathrm{EU}}$} & \multicolumn{3}{|c|}{$\overline{\mathrm{UE}}$} & \multicolumn{3}{|c|}{ EN } & \multicolumn{3}{|c|}{$\overline{\mathrm{UN}}$} \\
\hline Change since February 2020 & Spring & Summer & Fall & Spring & Summer & Fall & Spring & Summer & Fall & Spring & Summer & Fall \\
\hline Average & & & & & & & & & & & & \\
\hline W/o controlling for occupation & 2.9 & 1.9 & 0.5 & -0.3 & -0.5 & -0.8 & 0.2 & 0.2 & 0.1 & 0.1 & 0.1 & 0.1 \\
\hline Share women & 65.1 & 65.8 & 70.4 & 57.6 & 63.8 & 60.9 & 68.8 & 79.1 & 55.8 & 71.0 & 61.1 & 60.7 \\
\hline Controlling for occupation & 1.8 & 1.3 & 0.8 & -0.4 & -0.3 & -0.5 & 0.2 & 0.1 & 0.1 & 0.0 & 0.0 & 0.1 \\
\hline Share women & 66.8 & 59.4 & 57.3 & 72.5 & 96.1 & 79.4 & 55.4 & 101.8 & 67.2 & 120.4 & 107.8 & 64.5 \\
\hline Men & & & & & & & & & & & & \\
\hline Single w/o children & $1.57^{* * *}$ & $1.08^{* * *}$ & $0.78^{* *}$ & -0.54 & -0.33 & -0.35 & $0.32^{* *}$ & 0.01 & 0.06 & 0.02 & 0.06 & 0.09 \\
\hline Single with children & -0.22 & 1.12 & 0.34 & -0.88 & -1.25 & -1.57 & $-0.39^{*}$ & -0.43 & -0.22 & $-0.04^{*}$ & 0.14 & -0.01 \\
\hline Married w/o children & $0.77^{*}$ & $1 * * *$ & $0.64^{* *}$ & 0.64 & 0.67 & 0.49 & 0 & 0.06 & $0.16^{*}$ & 0 & -0.04 & $0.06^{*}$ \\
\hline Married with children & $1.38^{* * *}$ & $1.07^{* * *}$ & $0.74^{* * *}$ & -0.45 & -0.04 & -0.44 & 0.09 & -0.03 & 0.08 & -0.02 & -0.07 & -0.02 \\
\hline Women & & & & & & & & & & & & \\
\hline Single w/o children & $2.2^{* * *}$ & $1.17^{* * *}$ & $0.89^{* * *}$ & -0.72 & -0.77 & -0.67 & 0.2 & $0.26^{* * *}$ & $0.16^{*}$ & 0.05 & $0.16^{* *}$ & 0.09 \\
\hline Single with children & $1.85^{* *}$ & $2.46^{* * *}$ & $1.16^{* *}$ & -0.08 & 0.83 & -0.35 & 0.31 & 0.28 & 0.11 & 0.04 & -0.16 & 0 \\
\hline Married w/o children & $2.09^{* * *}$ & $1.56^{* * *}$ & $0.73^{* *}$ & -0.33 & -0.49 & -0.63 & 0.03 & $0.16^{*}$ & 0.12 & 0 & -0.02 & 0.11 \\
\hline Married with children & $2.81^{* * *}$ & $1.28^{* * *}$ & $0.97^{* * *}$ & -0.64 & -0.62 & $-1.1 * *$ & 0.19 & $0.18^{*}$ & $0.21^{* *}$ & 0 & 0.07 & 0.05 \\
\hline
\end{tabular}

The table reports selected estimates from specification 2 for labor flows EU, UE, EN, UN. The full set of estimates are reported in the Online Appendix. Phases of the pandemic correspond to March to May for Spring, June to August for Summer, September to December for Fall. The average effect is obtained by summing the contribution of each demographic group, obtained by multiplying the corresponding estimated effect for each phase of the pandemic with the group's population share in February 2020. The average effect is reported for the specification without and with occupational controls. In each case, "Share women" is the sum of all female contributions divided by the average effect for the specification with occupation controls. The effects by demographic groups are reported for the specification with occupational controls. Asterisks denote significance levels, * for $10 \%,{ }^{* *}$ for $5 \%$ and ${ }^{* * *}$ for $1 \%$. Population shares In February 2020 are reported in the Online Appendix. All values in percentage. Source: Authors' calculations based on CPS.

women in 1976-2007 (see Albanesi and Şahin (2018)). Women contribute to $67 \%$ of this rise in the spring, $59 \%$ in the summer and $57 \%$ in the fall, controlling for occupations, which is lower than women's share without occupation controls in spring and summer, suggesting that the occupation distribution substantially contributes to explaining gender differences in EU flows over that period. This can be seen in Figure 4, which displays the gender gaps by demographic groups with and without occupation controls. These gaps are substantial in spring and summer for all demographic groups, ranging from 1 percentage point for single without children to 2.2 percentage points for married with children in spring, and ranging from 0.5 percentage points for single without children to 1.5 percentage points for single with children in summer. Controlling for occupations mostly eliminates the gender differences in summer and fall, though they remain significant and sizable for spring, at approximately 1.25 percentage points for married workers and 2 percentage points for workers who are single with children. These results suggest married women and single women with children were disproportionately impacted by job losses in the spring, beyond the effects associated with their occupation distribution.

Turning to UE flows, they show a substantial decline of 0.3 percentage points in spring, 0.5 percentage points in summer and 0.8 percentage points in fall, suggesting that the labor market has not yet reached a recovery phase. Occupational controls reduce the magnitude of the effect of the pandemic in summer and fall, though most of the effects by demographic group and corresponding gender gaps are not statistically significant. 


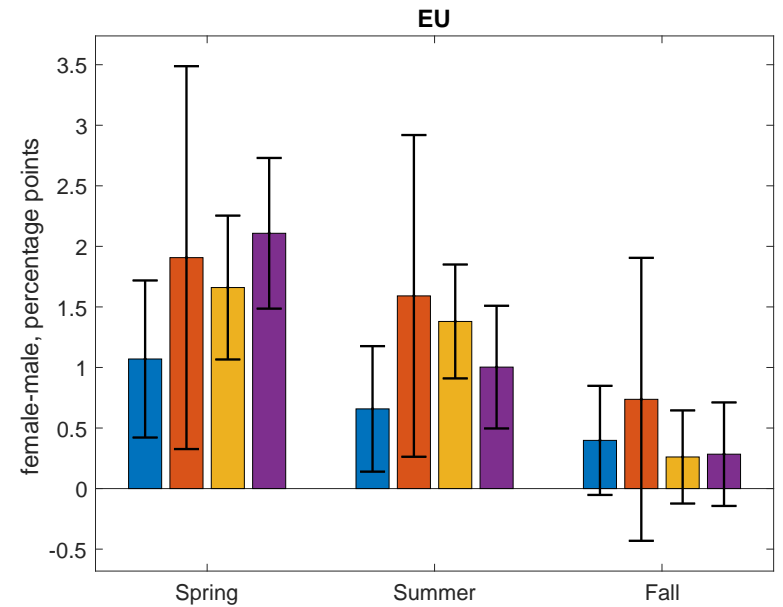

(a) Without occupation controls

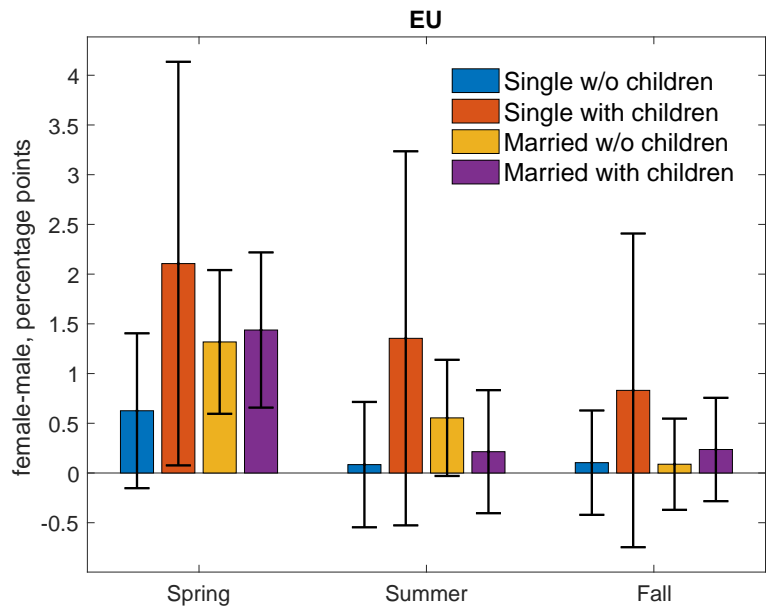

(b) With occupation controls

Figure 4: Female-male difference in changes in EU flows since February 2020, estimated from equation 2 with and without occupation controls. See note to Table 5 . Error bars denote $90 \%$ confidence intervals. Source: Author's calculations from CPS.

For the flows into non-participation, we find a substantive rise during the pandemic with a sizable gender difference. EN flows rose 0.2 percentage points in spring, and by 0.1 percentage points in summer and fall. This is a very large increase as the average EN flows have averaged approximately 0.023 for men and 0.035 for women in recent years (Albanesi and Şahin (2018)). Controlling for occupation moderates this rise only for the summer. While the contributions to the rise in EN were similar by sex in the spring, women account for $102 \%$ of the increase in EN for the summer and $67 \%$ for the fall controlling for occupation. Married women with children in the fall and single women without children in the summer and single men without children in the spring display the largest increases to the rise in EN. By contrast EN falls of single men with children in all phases of the pandemic, and for married men with children in the summer. As shown in Figure 5. controlling for occupations, the gender differences in the change in EN are only significant for single women with children in the spring and summer, for whom EN rises by 0.7 percentage points more than comparable men, and married women with children in the summer, for whom EN rises by 0.2 percentage points more than for comparable men. Turning to UN flows, we find that there is an increase of 0.1 percentage points during the pandemic. This rise is disproportionately accounted for by women, controlling for occupation, particularly in the spring and summer, however we do not find significant gender differences by demographic group.

The disproportionate rise in EN flows for women during the pandemic is striking, as it follows several decades of continued convergence in EN flows across genders (Albanesi and Şahin (2018)). Historically, women have exhibited higher EN flows than men, with most of the difference accounted for by men's higher rate of job to job transition (EE flows), with the gap mostly accounted for by 


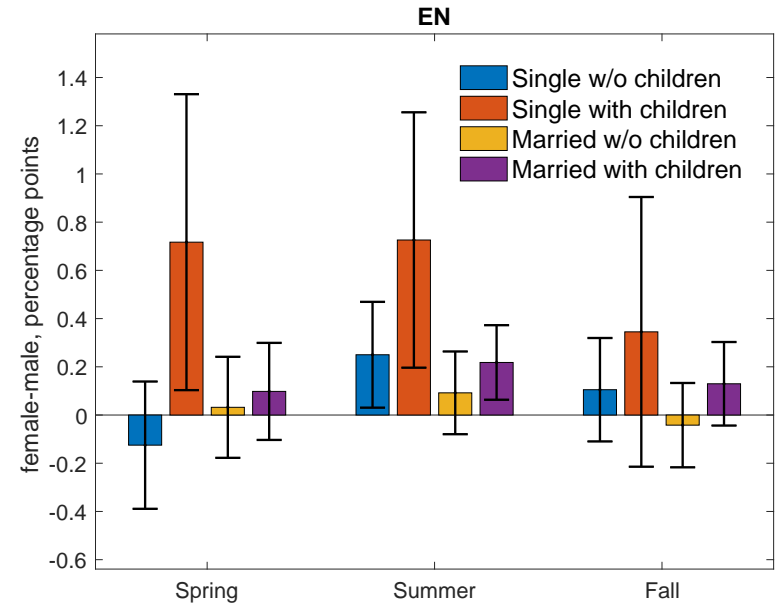

(a) EN, with occupation controls

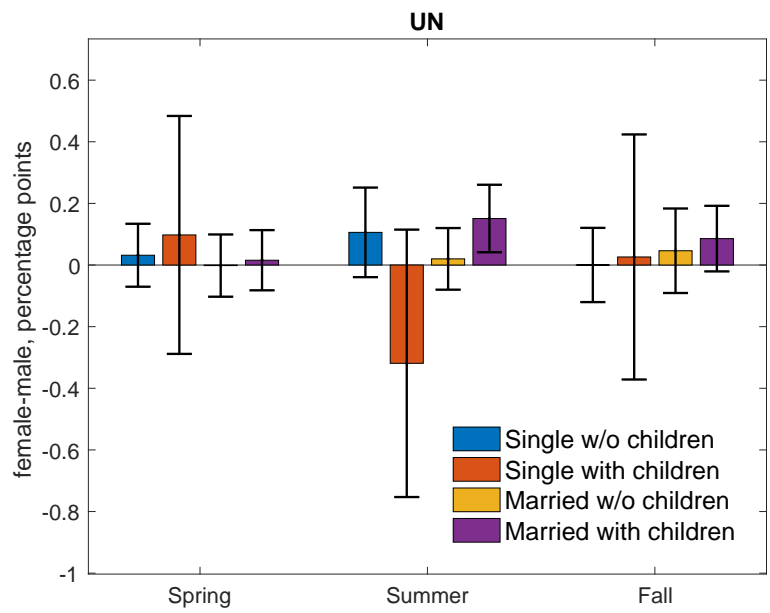

(b) UN, with occupation controls

Figure 5: Female-male difference in changes in EN and UN flows since February 2020, estimated from equation 2 with occupation controls. See note to Table 5 . Error bars denote $90 \%$ confidence intervals. Source: Author's calculations from CPS.

women's tendency to exit the labor force temporarily after the birth of a child (Royalty (1998)). However, as women's participation has grown, there has been a decline in their EN transition rates. Additionally, as shown in Ellieroth (2019), women's EN flow rate tends to fall in recessions. We do not find significant gender differences in the behavior of UN flows during the pandemic It bears noting that historically UN flows have been higher for women than for men. However, women's increased labor force attachment has determined a converge (Albanesi and Şahin (2018)) that has considerably contributed to increasing the average duration of unemployment in the United States since the early 1990s (Abraham and Shimer (2001)).

\subsection{Comparison to the Great Recession}

To understand how the pandemic recession differs from a standard business cycle, we replicate the previous analysis for the great recession. We estimate a version of equation 2, where the prerecession phase corresponds to March 2007 to November 2007, and we consider 3 phases of the subsequent business cycle. The Recession phase, December 2007 to June 2009, which corresponds to the NBER recession dates, the Recovery 1 phase, July 2009 to December 2010, and the Recovery 2 phase, January 2011 to July 2012. We split the recovery in two phases, as most labor market indicators substantially lagged GDP and aggregate demand during the first part of the recovery. The full regression results are reported in the Online Appendix, Table 6 reports the average effects on the recession in the three phases and the contribution of women and Figure 7 displays the gender differences by demographic group for the most salient variables.

Employment falls 2.5 percentage points on average in the Recession phase, and by 1.7 percentage 
points in the Recovery 1 phase, and returns to pre-recession levels in the Recovery 2 phase, without controlling for occupations. The share of employment changes accounted for by women is only $11 \%$ in the Recession phase, and rises to $33 \%$ in the recovery 1 phase. Adding occupation controls attenuates the average employment decline in the Recession phase, but increases it substantially in the two recovery phases, and increases the share of the change in employment accounted for by women to $43 \%$ in the Recession phase, $49 \%$ in the Recovery 1 phase and $52 \%$ in the Recovery 2 phase. These results suggest that the occupational distribution is a significant factor in women's smaller losses in employment compared to men. This is confirmed in Figure 6, where panels (a) and (b) display the gender differences by demographic group for employment, with and without occupational controls.

Women's employment losses are sizably smaller than men's for every demographic group in the specification without occupational controls. Among single workers without children, women's employment falls by 2 percentage points less than men's in the Recession phase, and 2.5 percentage points less in the Recovery 1 phase. Among single parents, women's employment falls by 3 percentage points less than men's in both the Recession and Recovery 1 phase. The gender gaps for married workers are smaller, with women's employment dropping by 1 percentage point less than men's in the Recession phase. In the recovery phase, among married workers without children, the drop in women's employment is 1.5 percentage points smaller than men's, while it is 1 percentage point smaller for married parents. In the Recovery 2 phase, the gender gap is still sizable for single workers without children, with women's employment dropping 1.5 percentage points less than men's, while gender gaps decline substantially in magnitude for the other demographic groups. Controlling for occupation eliminates gender gaps for married workers in all phases. For single workers without children, gender gaps are reduced by about half in all phases. For single parents, gender gaps also shrink by half in the Recession and Recovery 1 phase, while in during Recovery 2 women's employment drop is 0.75 percentage points bigger than men's. The pattern is similar for unemployment and EU flows, suggesting that women perform better than men during the great recession and the ensuing recovery. While the occupational distribution accounts for most of the gender difference in employment and unemployment changes for married workers, single women retain an advantage compared to single men at the trough of the recession and its immediate aftermath.

Turning to non-participation, it rose on average by 0.3 percentage points relative to pre-recession in the Recession and Recovery 1 phase, and by 0.2 percentage points in the Recovery 2 phase, without controlling for occupation, with women accounting for approximately $85 \%$ of this change. However, once occupation controls are included, average non-participation decreases by 0.1 percentage points at every stage of the cycle, with women accounting for $74-82 \%$ of this change. The bottom panels in Figure 6 display the gender gaps by demographic groups, with and without occupation controls. In the specification without occupational controls, men's non-participation rises by more than women for every demographic group, with the largest gender gaps recorded for single parents. 
Table 6: Employment, Unemployment, Non-participation by Demographic Group, Great Recession

\begin{tabular}{|c|c|c|c|c|c|c|c|c|c|}
\hline \multirow{2}{*}{ Change since pre-recession } & \multicolumn{3}{|c|}{ Employment } & \multicolumn{3}{|c|}{ Unemployment } & \multicolumn{3}{|c|}{ Non-participation } \\
\hline & Recession & Recovery 1 & Recovery 2 & Recession & Recovery 1 & Recovery 2 & Recession & Recovery 1 & Recovery 2 \\
\hline \multicolumn{10}{|l|}{ Average } \\
\hline W/o controlling for occupation & -2.5 & -1.7 & 0.0 & 2.6 & 1.8 & 0.0 & 0.3 & 0.3 & 0.2 \\
\hline Share women & 11.4 & 33.1 & 38.8 & 16.8 & 34.9 & 40.7 & 85.9 & 84.0 & 84.5 \\
\hline Controlling for occupation & -1.4 & -2.7 & -1.7 & 1.5 & 2.8 & 1.8 & -0.1 & -0.1 & -0.1 \\
\hline Share women & 43.0 & 48.7 & 52.4 & 45.0 & 50.0 & 54.0 & 80.6 & 81.6 & 74.1 \\
\hline \multicolumn{10}{|l|}{ Men } \\
\hline Single w/o children & $-2.4^{* * *}$ & $-4.46^{* * *}$ & $-2.81^{* * *}$ & $2.4^{* * *}$ & $4.48^{* * *}$ & $2.89^{* * *}$ & 0 & -0.01 & -0.07 \\
\hline Single with children & $-4.25 * * *$ & $-6.23^{* * *}$ & $-3.55^{* * *}$ & $4.19^{* * *}$ & $6.24^{* * *}$ & $3.56^{* * *}$ & 0.05 & 0 & 0 \\
\hline Married w/o children & $-1.19^{* * *}$ & $-1.86^{* * *}$ & $-0.81^{* * *}$ & $1.27^{* * *}$ & $1.9^{* * *}$ & $0.87^{* * *}$ & -0.07 & -0.04 & -0.06 \\
\hline Married with children & $-0.96^{* * *}$ & $-1.74^{* * *}$ & $-0.9^{* * *}$ & $1.01^{* * *}$ & $1.81^{* * *}$ & $0.98^{* * *}$ & -0.04 & -0.07 & $-0.07^{*}$ \\
\hline \multicolumn{10}{|l|}{ Women } \\
\hline Single w/o children & $-1.09^{* * *}$ & $-3.09^{* * *}$ & $-2.07^{* * *}$ & $1.23^{* * *}$ & $3.26^{\text {*** }}$ & $2.21^{* * *}$ & $-0.13^{* * *}$ & $-0.16^{* * *}$ & $-0.13^{* * *}$ \\
\hline Single with children & $-2.34^{* * *}$ & $-5.1 * * *$ & $-4.43^{* * *}$ & $2.46^{* * *}$ & $5.3^{* * *}$ & $4.78^{* * *}$ & -0.11 & $-0.19^{*}$ & $-0.34^{* * *}$ \\
\hline Married w/o children & $-1.01^{* * *}$ & $-1.73^{* * *}$ & $-0.99^{* * *}$ & $1.13^{* * *}$ & $1.87^{* * *}$ & $1.12^{* * *}$ & $-0.11^{*}$ & $-0.14^{* * *}$ & $-0.13^{* * *}$ \\
\hline Married with children & $-0.98^{* * *}$ & $-2.07^{* * *}$ & $-1.08^{* * *}$ & $1.11^{* * *}$ & $2.27^{* * *}$ & $1.32^{* * *}$ & $-0.11^{*}$ & -0.19 & $-0.24^{* * *}$ \\
\hline
\end{tabular}

The table reports selected estimates from specification 2 for employment, unemployment and non-participation. The full set of estimates are reported in the Online Appendix. Pre-recession corresponds to March 2007 to November 2007. Phases of the great recession correspond to December 2007 to June 2009 for Recession, July 2009 to December 2010 for Recovery 1, and January 2011 to July 2012 for Recovery 2. The average effect is obtained by summing the contribution of each demographic group, obtained by multiplying the corresponding estimated effect for each phase of the pandemic with the group's population share pre-recession. The average effect is reported for the specification without and with occupational controls. In each case, "Share women" is the sum of all female contributions divided by the average effect for the specification with occupation controls. Population shares pre-recession are reported in the Online Appendix. The effects by demographic groups are reported for the specification with occupational controls. Asterisks denote significance levels, ${ }^{*}$ for $10 \%,{ }^{* *}$ for $5 \%$ and $* * *$ for $1 \%$. All values in percentage. Source: Authors' calculations based on CPS.

In the specification with occupation controls, non-participation declines by more for women than for men, and gender gaps are most pronounced for single parents and married parents in the Recovery 2 phase. Estimates for EN and UN flows confirm the pattern that prevails for non-participation.

\subsection{Discussion}

Our analysis suggests that during 2020, women with children experienced a substantial reduction in labor supply in addition to the losses in employment from the decline in demand for labor in service occupations most affected by the pandemic. This decline in labor supply was concentrated among married women in the fall and was likely driven by the increased childcare needs associated with the disruptions to school activities associated with the pandemic.

Why did mothers respond to the lack of predictable in person schooling activities in households where fathers are also present? Likely, gender norms played a role, but assuming that parents decide on the distribution of child supervision responsibilities in a cooperative fashion, this response should be driven by differences in the opportunity cost as measured by wages. It is well documented that in the United States and other advanced economies, there is a substantial child penalty for mothers that reduces their wages throughout the course of their lifetime (Cortes and Pan (2020)). The penalty is driven by a combination occupational choices, labor supply on the intensive and extensive margin, and differences in wages, that begin well before women have children and have an 


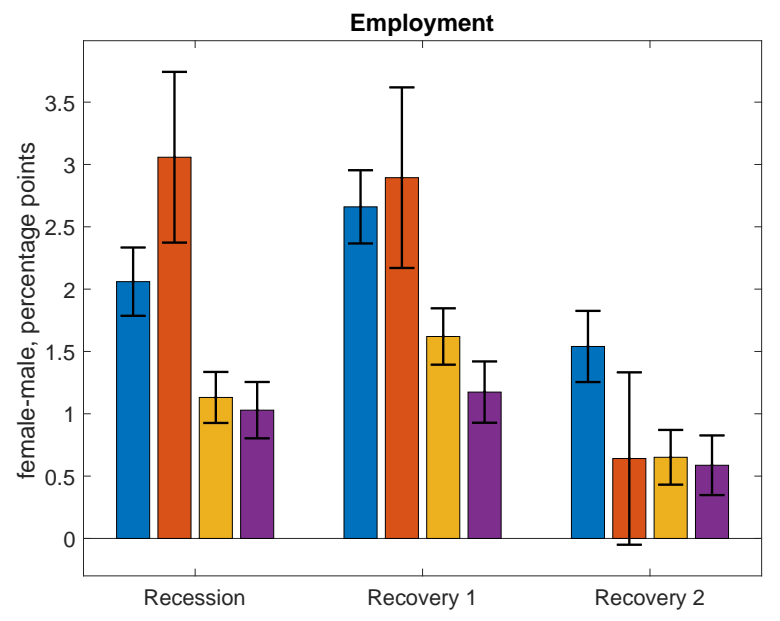

(a) Without occupation controls

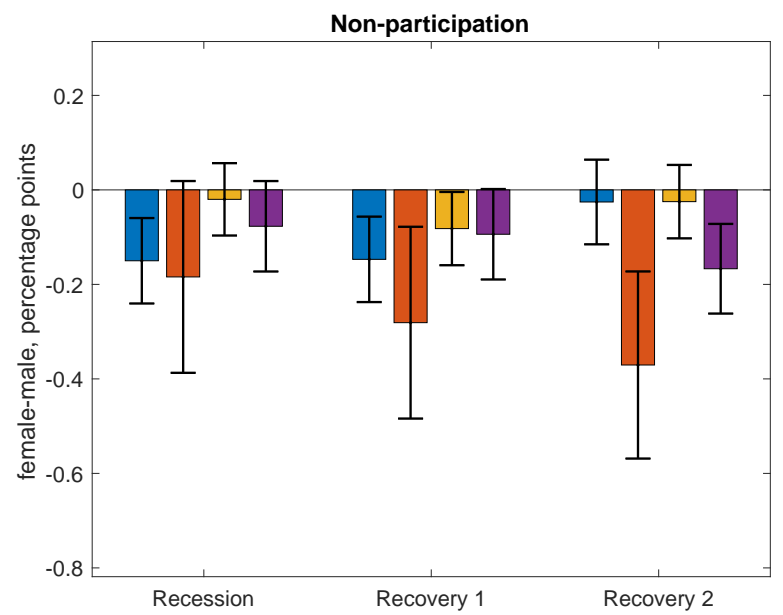

(c) Without occupation controls

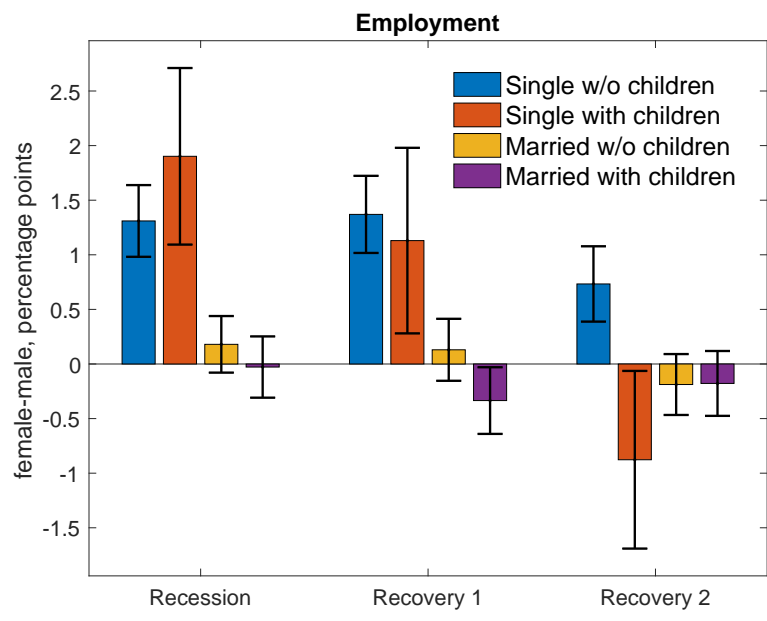

(b) With occupation controls

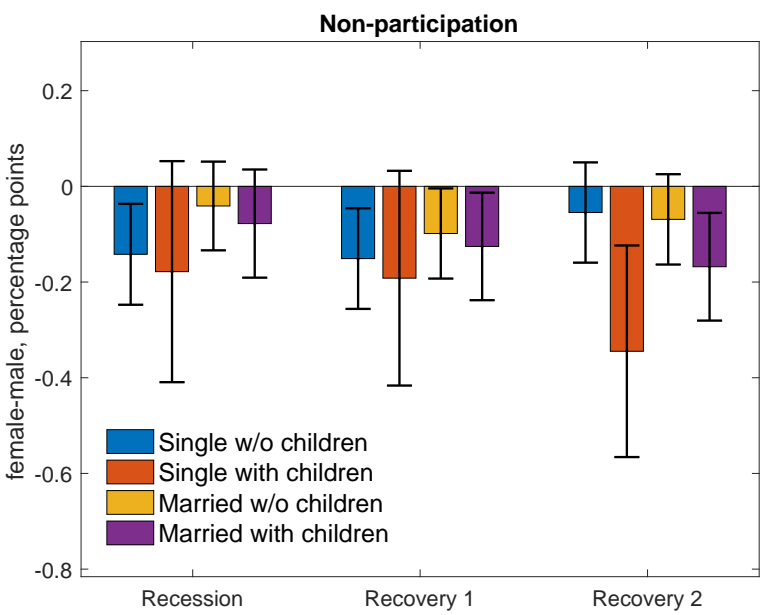

(d) With occupation controls

Figure 6: Female-male difference in changes in unemployment since March-November 2007, estimated from equation 2 with and without occupation controls for the great recession. See note to Table 6. Error bars denote 90\% confidence intervals. Source: Author's calculations from CPS. 
effect throughout their working lives (Kleven, Landais, and Søgaard (2019) and Adda, Dustmann,

and Stevens (2017)). The mean child penalty can be decomposed into explained effects, such as differences in mean values of background characteristics like education and race, and unexplained effects, which include the child penalty and different returns on non-child characteristics for mothers, compared to non-mothers or men. Cortes and Pan (2020) estimate that the long run child penaltythree years or more after having the first child-for US mothers is $39 \%$ and they also find that child related penalties account for two thirds of the overall gender wage gap in the last decade.

Given the child penalty, most working mothers at the start of the pandemic were likely to be earning less than their spouses, and for those households the optimal response to the increased child supervision needs was for mothers to reduce labor supply. This option would be available to families for whom husbands' earnings are high enough. While this prediction is hard to test in real time given the unavailability of data on earnings by labor market transition at a monthly frequency, if this mechanism is at play, we should observe two patterns as the pandemic hits. First, earnings for husbands whose wives remain in the labor force should fall compared to those of husbands whose wives do not participate. Second, for two earner households, earnings of wives who remain employed should rise compared to their husbands. Figure 7 displays evidence that is broadly consistent with these patterns. The left panel displays husbands' weekly earnings by their wives' employment status in February 2020 and in the three phases of the pandemic. Compared to February 2020, earnings for husbands with employed wives fall in comparison to those of husbands whose wives are out of the labor force. However, the differences in weekly earnings are relatively small, and revert to pre-pandemic levels by fall. The right panel displays the wife/husband wage ratio for two earner couples. This ratio increased from $85 \%$ in February 2020 to $102 \%$ in spring 2020 and remained elevated at $98 \%$ in summer, though it dropped to pre-pandemic levels by the fall. This evidence is consistent with the hypothesis the mothers' lower wages can explain their departure from the workforce in response to the childcare demands driven by the pandemic, but a deeper analysis is warranted as more data becomes available.

Of course, the child penalty may have affected the demand for women's labor during the pandemic, in addition to their labor supply. Cajner et al. (2020) show that employment losses were concentrated disproportionately among lower wage workers at the beginning of the pandemic and Chetty et al. (2020) find that by the fall, lower wage workers' employment was still more than $20 \%$ below pre-pandemic values, with a much larger recovery for higher wage workers. Given that the child penalty tends to relegate women at the lower end of the wage distribution, it may have also played a role in their disproportionate loss of employment during the spring.

\section{Continuing Impacts}

It is hard to grapple with the full extent and duration of the possible impact of COVID-19 on labor markets and the overall economy going forward. We focus on the prospective continuing effects 


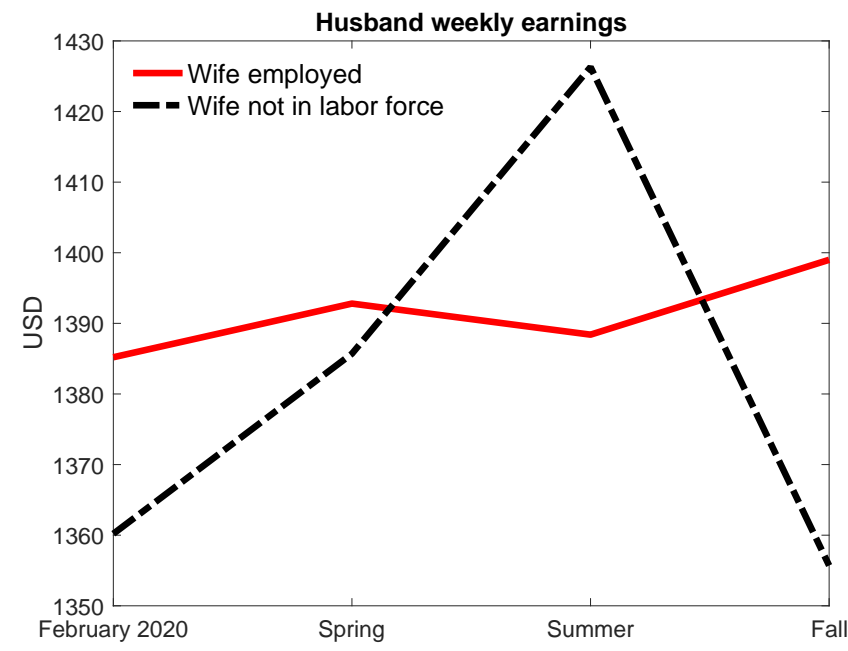

(a) Husband's weekly earnings by wife's employment status

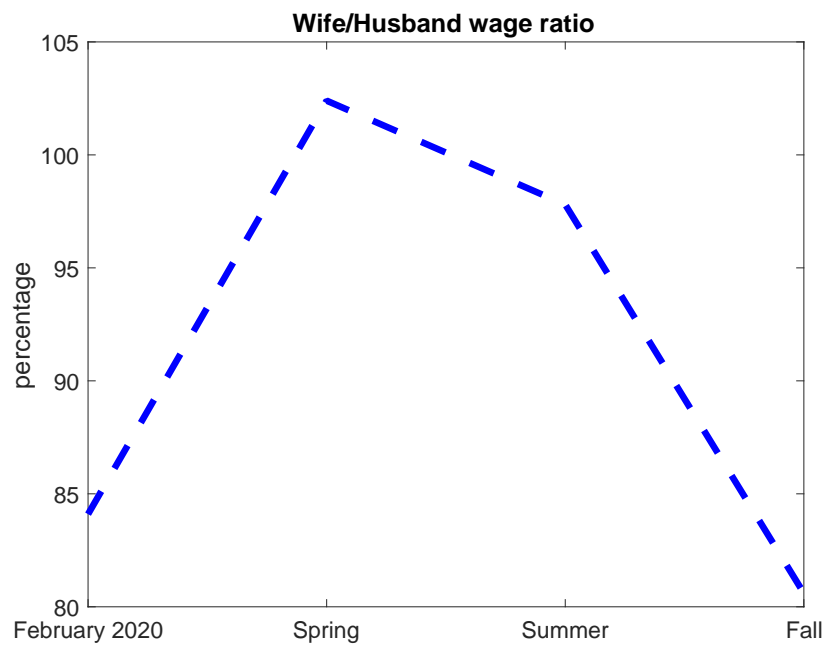

(b) Wife/husband wage ratio

Figure 7: Husband's weekly earnings by wife's employment status and wife/husband earning ratio for couples who are both employed in 2020. Spring corresponds to March-May, Summer to JuneAugust, Fall to September-December. Source: Author's calculations from CPS.

on women via the likely impact on their relative wages and on the whether the susceptibility to automation of the occupations most adversely affected by COVID-19 may impede a full recovery of aggregate employment.

\subsection{Gender Wage Gaps}

Working mothers have been disproportionately hit by employment losses during the pandemic, both in terms of labor demand and labor supply. This may have effects well beyond the duration of the pandemic. The impact on wages and lifetime earnings of mothers who leave the labor force temporarily to take care of children are substantial. Adda, Dustmann, and Stevens (2017) estimate that the component of the child penalty associated with "atrophy" during spells of nonparticipation, due to human capital depreciation or skill obsolescence, accounts for $13 \%$ of the overall gender wage gap. Additionally, employer investments in human capital and the career paths offered to women are affected by the expectation of career interruptions (Albanesi and Olivetti (2009)). After many decades of increasing labor market attachment for women (Goldin (2006)), the reduction in mother's labor supply associated with the pandemic may reverse the slow progress made in this area. Alon et al. (2020a) conjecture that the rise in remote work may help women, as it may increase sharing of child care responsibilities with fathers now working remotely. While this may be a possibility for some parents, the rise in mothers' non-participation during the pandemic suggests that in the aggregate this is unlikely to play a large role. In addition, remote work has grown for most classes of workers during the pandemic, but it has increased considerably more for 
women (Bick, Blandin, and Mertens (2020)). Lack of flexibility has long been seen as a barrier to women's career advancement (Goldin (2014), Cortés and Pan (2019)), and increased ability to work remotely, which is expected to continue after the pandemic, when child care needs are normalized, may benefit women. However, if it is mostly women who continue to take advantage of remote work arrangements, they may be stigmatized and miss out on career advancement opportunities, particularly in highly competitive professional and managerial occupations.

\subsection{Employment Recovery}

A critical question as we look forward to the end of the pandemic is whether employment will return to pre-pandemic level and jobs that were lost during the pandemic will be reinstated. While employment losses during the pandemic were concentrated in occupations and industries that typically fare well during standard recessions, we can still examine the patterns of labor market recovery in recent business cycles to gain some perspective. Since the 1990 recession, the US has experienced "jobless recoveries," that is, even as GDP and aggregate demand rebound from the trough of the cycle, labor market indicators continue to stagnate and employment struggles to attain pre-recession levels. Two main factors appear to be behind this phenomenon.

Albanesi (2019) argues that the subdued behavior of employment during recoveries since the 1990s is driven by the flattening of female labor force participation over that period. Recoveries have always been jobless for men, but as long as female labor force participation was rising, female employment tended to grow very rapidly in recoveries, leading to faster growth in aggregate employment. Since female participation stopped trending upwards, the rate of growth of women's employment during recoveries has been similar to men's, leading to sluggish performance in the aggregate. Given that women have been more strongly affected by the pandemic and that their labor force participation has fallen, while it does not usually decline in recessions, if the recovery from the pandemic is associated with a rebound of female participation to pre-pandemic levels this may lead to a more energetic and faster recovery in aggregate employment compared to recent cycles. However, a second explanation for jobless recoveries points in the opposite direction. The hypothesis is that the slow and incomplete rebound of aggregate employment is due structural change leading to a permanent decline in manufacturing employment (Groshen and Potter (2003)) and routine jobs (Jaimovich and Siu (2020)). While these phenomena are driven by slow moving trends in technology, the job losses associated with the resulting restructuring are concentrated in recessions. As the economy recovers, those jobs are not reinstated and firms meet the rebound in demand with labor saving new technologies. This phenomenon affects primarily middle skill jobs which are particularly cyclical (Foote and Ryan (2015)), and is a key mechanism through which the trend toward job polarization (Acemoglu and Autor (2011)) has affected business cycles.

While the pandemic has affected service occupations that have been less sensitive to standard business cycle variation and may seem less amenable to automation, it is useful to examine whether there is the potential to replace the workers who have been laid off during the pandemic with 
technologies. Embracing automation, software and AI to reduce labor intensity, as demand recovers post-pandemic, has the added advantage of saving employers from the costs of adapting workplaces and practices to mitigate the ongoing risk of infection that is expected to persist, as long as a substantial fraction of the world population does not have access to vaccines and remains susceptible to the coronavirus. To examine the susceptibility to automation by occuption, we use two proxies. One is Routine Task-Intensity (RTI), an index developed in Autor and Dorn (2013) that calculates the routine, manual, and abstract task inputs in each occupation based on job task requirements from the Dictionary of Occupational Titles (DOT) 7 Higher values of RTI correspond to higher susceptibility to automation, and we classify occupations with above median RTI as High-RTI occupations. As an alternative, we also use the question 'How automated is your current job?' in $\mathrm{O}^{*} \mathrm{NET}$. Answers are on the scale of 1 (Not at all automated) to 5 (Completely automated). To derive an occupation based measure, we compute the average score for each occupation and classified occupations with score higher than the median as Highly Automatable occupations.

Table 7: Susceptibility to Automation by Occupation

\begin{tabular}{l|c|c}
\hline \hline Occupation & Share of High-RTI & Share of Highly Automatable \\
\hline Flexible, High-Contact & 9.1 & 8.2 \\
Flexible, Low-Contact & 63 & 61.3 \\
Inflexible, High-Contact & 45.3 & 40 \\
Inflexible, Low-Contact & 50.9 & 49.8 \\
\hline \hline All values in percentage. Source: Authors' calculations based on Autor and Dorn (2013) and O*NET.
\end{tabular}

The share of High-RTI occupations and Highly Automatable occupations in the four occupation categories we introduced in Section 3 are very similar and are reported in Table 7. We find that approximately $40-45 \%$ of the inflexible/high-contact occupations, the category most affected by the pandemic, are susceptible to automation. This is only slightly lower than for inflexible/low-contact occupations, the most exposed to standard recessions, of which approximately $50 \%$ are highly susceptible to automation. The most automatable occupational category is the flexible/low-contact, as it includes Office and Administrative and Sales and Related occupations, which are cognitive and routine. The least automatable group of occupations is flexible/high-contact comprised of Education, Training, and Library occupations. These findings suggest that even health care and personal service occupations are susceptible to automation, leaving open the possibility that employment losses in those occupations may not be fully reversed as the broader economy recovers from the pandemic.

Another factor that may prevent the full recovery of employment post-pandemic is the expected continuation of remote work for many workers in flexible/high contact occupations (Altig) et al. (2020)). The normalization of remote work may displace office time and business travel, leading to a permanent decline in the demand for building cleaning, security and maintenance ser-

\footnotetext{
${ }^{7}$ RTI is defined as the $\log ($ routine task input $)-\log ($ abstract task input $)$ - $\log$ (manual task input).
} 
vices, hospitality services, transportation and other support services (Autor and Reynolds (2020)). This raises the prospect that the workers employed in these jobs, mainly concentrated in the inflexible/high contact and inflexible/low-contact occupations based on our categorization, will not rebound to pre-pandemic level of employment.

\section{Conclusion}

The emergence of COVID-19 has been an unprecedented shock to labor markets in the United States and around the world. Unlike in standard recessions, the adverse impact of the pandemic on employment, unemployment and labor force participation has mostly hit women, particularly mothers. Both labor demand factors, such women's disproportionate representation in service occupations most vulnerable to the pandemic, and labor supply factors, like closures of childcare centers and in-person schools, contributed to this outcome. While the pandemic may end in the United States as vaccines become widely available, some of its labor market impacts may be long lived. The increase in non-participation for women will likely reduce their wages when they re-enter the workforce. Additionally, many occupations that have suffered from large employment losses during the pandemic are highly susceptible to automation. This raises the prospect that as the economy recovers, at least some of the jobs lost may not be reinstated. 


\section{References}

Abowd, John M, and Arnold Zellner. 1985. "Estimating gross labor-force flows." Journal of Business 86 Economic Statistics 3 (3): 254-283.

Abraham, Katharine G, and Robert Shimer. 2001, October. "Changes in Unemployment Duration and Labor Force Attachment." Working paper 8513, National Bureau of Economic Research.

Acemoglu, Daron, and David Autor. 2011. "Skills, tasks and technologies: Implications for employment and earnings." In Handbook of labor economics, Volume 4, 1043-1171. Elsevier.

Adda, Jérôme, Christian Dustmann, and Katrien Stevens. 2017. "The career costs of children." Journal of Political Economy 125 (2): 293-337.

Albanesi, Stefania. 2019, March. "Changing Business Cycles: The Role of Women's Employment." Working paper 25655, National Bureau of Economic Research.

Albanesi, Stefania, Rania Gihleb, Jialin Huo, and Jiyeon Kim. 2020. "Household insurance and the macroeconomic impact of the novel coronavirus." Unpublished Manuscript, University of Pittsburgh.

Albanesi, Stefania, and Claudia Olivetti. 2009. "Home production, market production and the gender wage gap: Incentives and expectations." Review of Economic dynamics 12 (1): 80-107.

Albanesi, Stefania, and Ayşegül Şahin. 2018. "The gender unemployment gap." Review of Economic Dynamics 30:47-67.

Alon, Titan, Matthias Doepke, Jane Olmstead-Rumsey, and Michle Tertilt. 2020a, April. "The Impact of COVID-19 on Gender Equality." Working paper 26947, National Bureau of Economic Research.

—. 2020b, August. "This Time It's Different: The Role of Women's Employment in a Pandemic Recession.” Working paper 27660, National Bureau of Economic Research.

Altig, David E, Jose Maria Barrero, Nicholas Bloom, Steven J Davis, Brent Meyer, Emil Mihaylov, and Nicholas B Parker. 2020. "Firms Expect Working from Home to Triple."

Autor, David, and Elisabeth Reynolds. 2020. "The nature of work after the COVID crisis: Too few low-wage jobs." The Hamilton Project, Brookings.

Autor, David H., and David Dorn. 2013. "The Growth of Low-Skill Service Jobs and the Polarization of the US Labor Market." American Economic Review 103 (5): 1553-97 (August).

Bick, Alexander, Adam Blandin, and Karel Mertens. 2020. "Work from home after the COVID-19 Outbreak."

Blau, Francine D, Josefine Koebe, and Pamela A Meyerhofer. 2020. "Who are the Essential and Frontline Workers?" Technical Report, National Bureau of Economic Research. 
Blundell, Richard, Luigi Pistaferri, and Itay Saporta-Eksten. 2016. "Consumption Inequality and Family Labor Supply." American Economic Review 106 (2): 387-435 (February).

Cajner, Tomaz, Leland D Crane, Ryan A Decker, John Grigsby, Adrian Hamins-Puertolas, Erik Hurst, Christopher Kurz, and Ahu Yildirmaz. 2020, May. "The U.S. Labor Market during the Beginning of the Pandemic Recession." Working paper 27159, National Bureau of Economic Research.

Chetty, Raj, John N Friedman, Nathaniel Hendren, Michael Stepner, and The Opportunity Insights Team. 2020. The economic impacts of COVID-19: Evidence from a new public database built using private sector data. National Bureau of Economic Research.

Cortes, Patricia, and Jessica Pan. 2018. "Occupation and gender." The Oxford handbook of women and the economy, pp. 425-452.

Cortés, Patricia, and Jessica Pan. 2019. "When time binds: Substitutes for household production, returns to working long hours, and the skilled gender wage gap." Journal of Labor Economics 37 (2): 351-398.

Cortes, Patricia, and Jessica Pan. 2020, October. "Children and the Remaining Gender Gaps in the Labor Market." Working paper 27980, National Bureau of Economic Research.

Cullen, Julie Berry, and Jonathan Gruber. 2000. "Does unemployment insurance crowd out spousal labor supply?" Journal of labor Economics 18 (3): 546-572.

Dingel, Jonathan I, and Brent Neiman. 2020. "How many jobs can be done at home?" Journal of Public Economics 189:104235.

Doepke, Matthias, and Michèle Tertilt. 2016. "Families in macroeconomics." In Handbook of macroeconomics, Volume 2, 1789-1891. Elsevier.

Ellieroth, Kathrin. 2019. "Spousal Insurance, Precautionary Labor Supply, and the Business Cycle." Technical Report, Indiana University.

Elsby, Michael W.L., Bart Hobijn, and Aysegul Sahin. 2015. "On the importance of the participation margin for labor market fluctuations." Journal of Monetary Economics 72:64-82.

Foote, Christopher L, and Richard W Ryan. 2015, March. "Labor Market Polarization Over the Business Cycle." Working paper 21030, National Bureau of Economic Research.

Goldin, Claudia. 2006. "The quiet revolution that transformed women's employment, education, and family." American economic review 96 (2): 1-21.

- 2014. "A grand gender convergence: Its last chapter." American Economic Review 104 (4): 1091-1119.

Groshen, Erica L, and Simon Potter. 2003. "Has structural change contributed to a jobless recovery?" Current Issues in Economics and Finance 9, no. 8. 
Jaimovich, Nir, and Henry E Siu. 2020. "Job polarization and jobless recoveries." Review of Economics and Statistics 102 (1): 129-147.

Juhn, Chinhui, and Simon Potter. 2007. "Is there still an added-worker effect?" FRB of New York Staff Report, no. 310.

Kleven, Henrik, Camille Landais, and Jakob Egholt Søgaard. 2019. "Children and gender inequality: Evidence from Denmark." American Economic Journal: Applied Economics 11 (4): 181-209.

Krusell, Per, Toshihiko Mukoyama, Richard Rogerson, and Aysegul Sahin. 2017. "Gross Worker Flows over the Business Cycle." American Economic Review 107 (11): 3447-76 (November).

Lee, Sang Yoon Tim, Minsung Park, and Yongseok Shin. 2021. "Hit Harder, Recover Slower? Unequal Employment Effects of the Covid-19 Shock." Technical Report, National Bureau of Economic Research.

Lundberg, Shelly. 1985. "The added worker effect." Journal of Labor Economics 3 (1, Part 1): $11-37$.

Mankart, Jochen, and Rigas Oikonomou. 2017. "Household search and the aggregate labour market." The Review of Economic Studies 84 (4): 1735-1788.

Mincer, Jacob. 1991. "Education and unemployment." Technical Report, National Bureau of Economic Research.

Olsson, Jonna. 2019. "Structural transformation of the labor market and the aggregate economy." Technical Report, Unpublished Manuscript, University of Amsterdam.

Ortigueira, S., and N. Siassi. 2013. "How important is intra-household risk sharing for savings and labor supply?" Journal of Monetary Economics 60(6):650-666.

Park, Seonyoung, Donggyun Shin, et al. 2020. "Welfare consequences of rising wage risk in the United States: Self-selection into risky jobs and family labor supply adjustments." Technical Report.

Parker, Susan W, and Emmanuel Skoufias. 2004. "The added worker effect over the business cycle: evidence from urban Mexico." Applied Economics Letters 11 (10): 625-630.

Ravn, Morten O, and Harald Uhlig. 2002. "On adjusting the Hodrick-Prescott filter for the frequency of observations." Review of economics and statistics 84 (2): 371-376.

Royalty, Anne Beeson. 1998. "Job-to-job and job-to-nonemployment turnover by gender and education level." Journal of labor economics 16 (2): 392-433.

Shimer, Robert. 1998. "Why is the US unemployment rate so much lower?" NBER Macroeconomics Annual 13:11-61.

Shore, Stephen H. 2010. "For better, for worse: Intrahousehold risk-sharing over the business cycle." The Review of Economics and Statistics 92 (3): 536-548. 
Stephens, M. Jr. 2002. "Worker displacement and the added worker effect." Journal of Labor Economics 20(3):504-537.

Taylor, Paul. 2010. "The Decline of Marriage and Rise of New Families." Pew research center.

Wu, Chunzan, and Dirk Krueger. 2021. "Consumption insurance against wage risk: Family labor supply and optimal progressive income taxation." American Economic Journal: Macroeconomics 13 (1): 79-113. 


\section{Appendix}

\section{A Data}

We use monthly data from the Current Population Survey (CPS) between January 2020 and November 2020. The sample includes workers of age from 25 to 54. Armed force excluded. Those whose current or past occupation information is unavailable are excluded. The labor market statuses are divided into three groups: Employed, Unemployed, Not in the Labor Force. The distinction across categories follows the definition from the CPS except that those who report being employed but absent from work for no particular reasons are classified as unemployed. The stock variables are based on the repeated cross-sectional data. To construct the labor status transitions, we utilize the panel structure of the CPS where the individuals are surveyed for four consecutive months, absent from the survey for eight months, and then re-surveyed for another four months. We match individual observations across consecutive months using the IPUMS-CPS identifier (CPSIDP). To verify the matching process, we made sure the matched-individuals have the consistent age, gender, and race. Using the IPUMS-CPS identifier gives us a 99 percent of matching success rate (In the analysis about the great recession, the success rate drops to 95 percent). With the panel data created, we calculate monthly labor market status transition for each individual. For example, if an individual reports being employed in month $t-1$ and not being in the labor force in month $\mathrm{t}$, we conclude they made a $\mathrm{E}$ to $\mathrm{N}$ transition in $t$.

For the analysis of husbands' earnings by wives' employment status, we use earnings information from the Outgoing Rotation Groups (Earner Study) in the CPS. The Outgoing Rotation Group consists of the households who are being interviewed for the fourth month or eighths month. Household members who are employed at the time are asked additional questions regarding earnings and hours worked. We identify married couples using SPLOC, the variable that gives the person number of a respondent?s spouse who lives in the same household. If a man-woman pair in the sample share the same household serial number and their SPLOC corresponds to each other?s person number, we consider them as a married couple.

\section{B Occupational Classification}

We create the measures of flexibility and physical contact intensity using data from the Occupational Information Network (O*NET). O*NET survey started in 1998 and updated on an irregular basis. We use the most recent version published in February 2020. O*NET survey asks a random sample of U.S. workers in each occupation various questions about typical work activities required in their occupations. Respondents answer each question on an ordinal scale of one to five. To measure occupations' flexibility, we take the average across respondents answers to the following fifteen questions:

- How frequently does your current job require electronic mail?

- How often is dealing with violent or physical aggressive people a part of your current job?

- How often does your current job require you to work outdoors, exposed to all weather conditions?

- How often does your current job require that you be exposed to diseases or infection? 
- How often does your current job require that you be exposed to minor burns, cuts, bites, or stings?

- How much time in your current job do you spend walking or running?

- In your current job, how often do you wear common protective or safety equipment such as safety shoes, glasses, gloves, hearing protection, hard hats, or life jackets?

- How important is inspecting equipment, structures, or materials to the performance of your current job?

- How important is performing general physical activities to the performance of your current job?

- How important is handling and moving objects to the performance of your current job?

- How important is controlling machines and processes to the performance of your current job?

- How important is operating vehicles, mechanized devices, or equipment to the performance of your current job?

- How important is repairing and maintaining mechanical equipment to the performance of your current job?

- How important is repairing and maintaining electronic equipment to the performance of your current job?

- How important is performing for or working directly with the public to the performance of your current job?

To compute the contact intensity measure, we use the following question asking about physical proximity to other people:

- How physically close to other people are you when you perform your current job?

Again, respondents answer on an ordinal scale of one to five. Unlike other questions, however, each number is assigned with a specific example describing the physical distance to other people (1: beyond $100 \mathrm{ft} ., 2$ : private office, 3: shared office, 4: at arm's length, 5: near touching). Table 8 presents the measures of flexibility and physical contact intensity by occupations' major groups. 
Table 8: Occupations by Flexibility and Contact Intensity

\begin{tabular}{clcc}
\hline SOC code & \multicolumn{1}{c}{ Occupation Group } & Inflexibility & Intensity \\
\hline 11 & Management & 2.0 & 3.0 \\
13 & Business & 1.5 & 2.8 \\
15 & Computer and Mathematical & 1.4 & 2.6 \\
17 & Architecture andEngineering & 2.1 & 3.0 \\
19 & Life, Physical and Social Science & 1.9 & 3.7 \\
21 & Community and, Social Services & 1.9 & 2.4 \\
23 & Legal & 1.6 & 4.3 \\
25 & Education, Training and Library & 2.1 & 3.2 \\
27 & Arts, Design, Entertainment, Sports, and Media & 1.8 & 4.4 \\
29 & Healthcare Practitioners, and Technical & 2.6 & 4.8 \\
31 & Healthcare Support & 2.6 & 3.8 \\
33 & Protective Service & 2.7 & 4.2 \\
35 & Food Preparation and Serving & 2.7 & 2.9 \\
37 & Building, Grounds Cleaning and Maintenance & 3.0 & 4.2 \\
39 & Personal Care and Service & 2.5 & 3.6 \\
41 & Sales and Related & 2.1 & 3.4 \\
43 & Office and Administrative & 2.1 & 3.3 \\
45 & Farming, Fishing and Forestry & 3.0 & 4.0 \\
47 & Construction Trades and Extraction & 3.3 & 3.4 \\
49 & Installation, Maintenance and Repair & 3.3 & 3.4 \\
51 & Production & 2.9 & 3.6 \\
53 & Transportation and Material Moving & 3.0 & \\
\hline \hline
\end{tabular}

Author's calculations based on O*NET. 


\section{Exposure to Standard Recessions by Occupation}

We report summary statistics on the cyclicality of employment by gender, marital status and occupation. We consider the four occupational categories defined in Section 3 and we measure employment as the employment to population ratio for each category of worker. We extract the cyclical component from the employment series with a Hodrick-Prescott filter with smoothing parameter $\lambda=6.5$. Flexible/Low contact occupation have the lowest standard deviation relative to GDP, whereas Inflexible/Low contact have the highest, though both have high correlations with GDP lagged by one year. Inflexible/High contact occupations have the lowest standard deviation relative to GDP and the lowest correlation.

Within occupation, there is a substantive difference in the standard deviation relative with and the correlation to GDP by gender and marital status. For both single and married workers, men display higher cyclicality, and the cyclicality is substantially higher for singles compared to married for both men and women. The gender differences in these measure of cyclicality are most pronounced for single workers. for all occupations other than Inflexible/High contact, there are only very small differences in cyclicality between married men and married women.

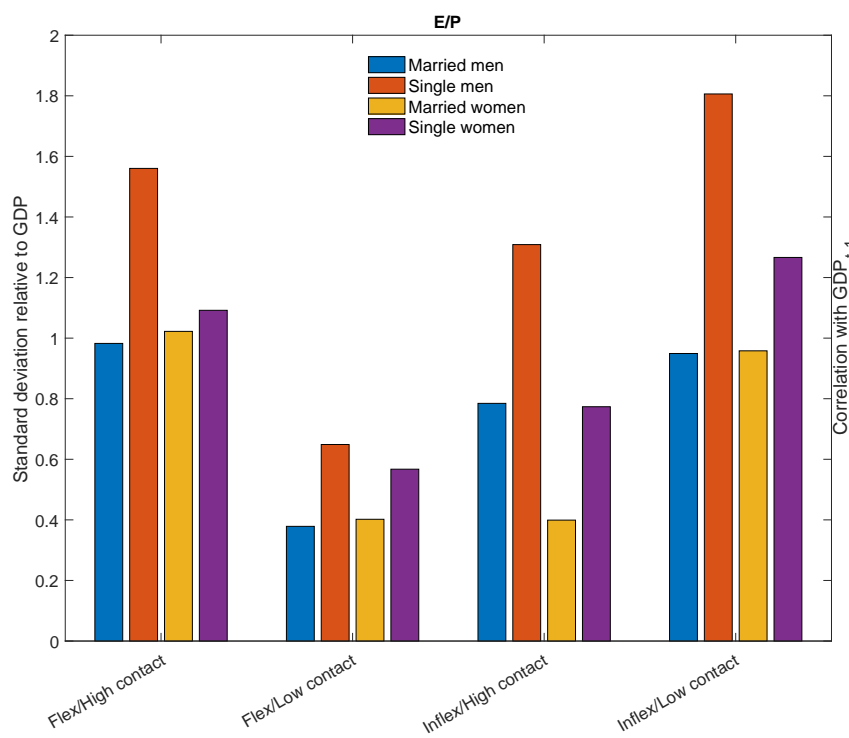

(a) Standard Deviation

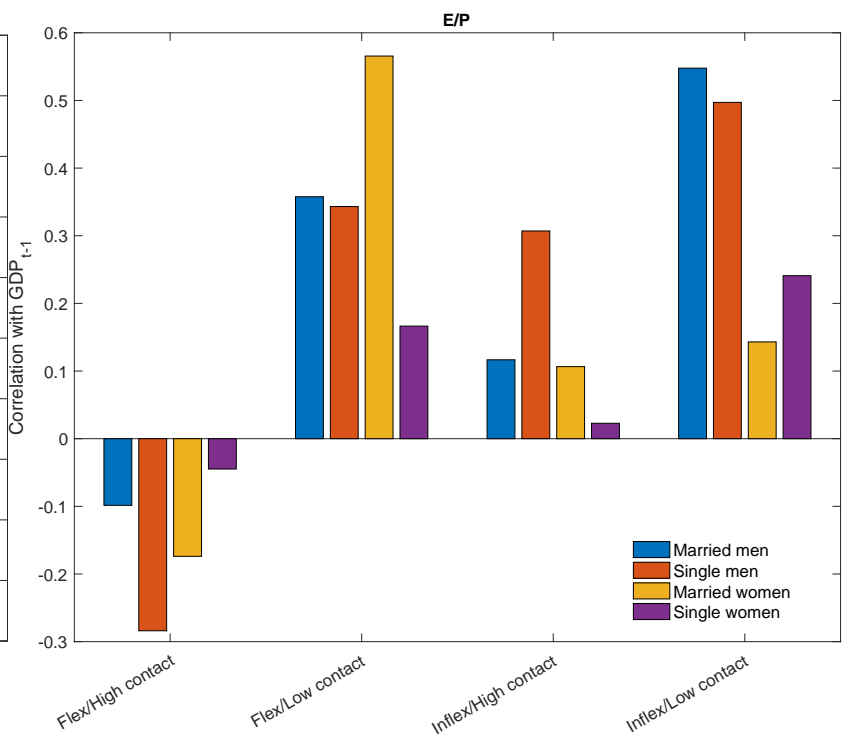

(b) Correlation

Standard deviation relative to and correlation with GDP per capita of E/P per capita by gender and marital status, $1976-2018$. Source: Albanesi et al. (2020) based on CPS March Supplement. 


\section{Regression Results}

We report the full set of estimation results for specification 2 estimated during the pandemic (Section 4) and during the great recession (Section 4.1). All specification include age and education controls. Individuals belong to one of the three age groups, aged 25-34, 35-44 and 45-54 years old. Likewise, we divide the sample into three education categories: high school degree or less, some college, and bachelor's degree or higher. To control any age-specific or education-specific impact of the pandemic, we include the age group dummies and education group dummies as well as their interactions with the recession phases in all specifications.

As the measure of occupation, we use the 2-digit Standard Occupational Classification (SOC) code provided by the CPS. To take into account the recessions' impact by occupation, we include 2-digit occupation dummies and their interactions with the recession phases.

The share in the population of each demographic group is reported in Table 9 .

Table 9: Share of Population by Demographic Group

\begin{tabular}{|c|c|c|c|c|c|c|c|c|}
\hline & \multicolumn{4}{|c|}{ Men } & \multicolumn{4}{|c|}{ Women } \\
\hline & \begin{tabular}{|l|} 
Single w/o children \\
\end{tabular} & Single with children & Married w/o children & Married with children & \begin{tabular}{|l} 
Single w/o children \\
\end{tabular} & Single with children & Married w/o children & Married with children \\
\hline February 2020 & 19.15 & 2.28 & 13.17 & 13.8 & 16.51 & 5.45 & 15.38 & 14.26 \\
\hline March-November 2007 & 16.49 & 1.94 & 14.71 & 15.06 & 14.1 & 5.36 & 17.14 & 15.2 \\
\hline
\end{tabular}

All values in percentage. Source: Authors' calculations from CPS.

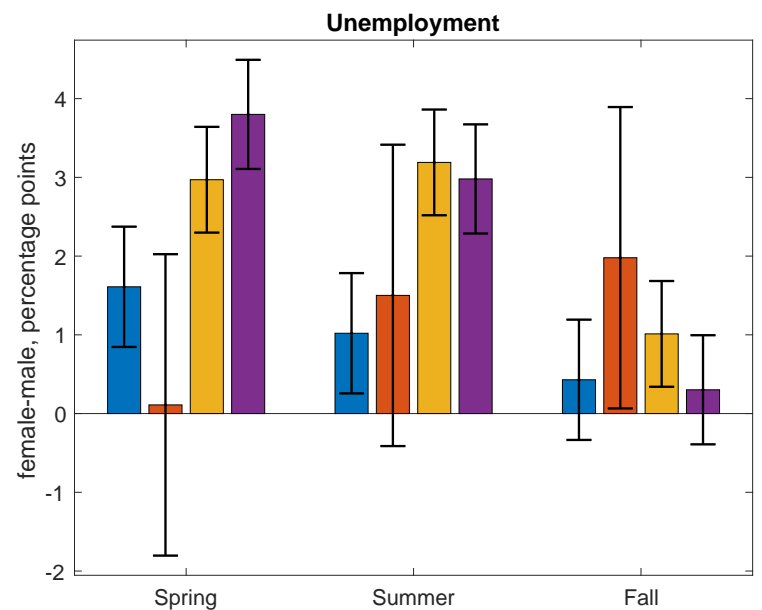

(a) Without occupation controls

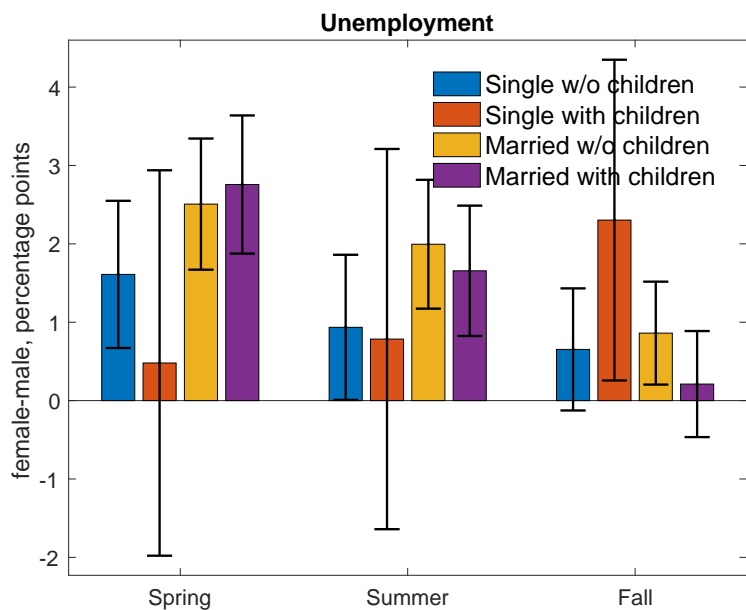

(b) With occupation controls

Figure 8: Female-male difference in changes in unemployment since February 2020, estimated from equation 2 with and without occupation controls. See note to Table 4 . Error bars denote $90 \%$ confidence intervals. Source: Author's calculations from CPS. 
Table 10: Regression Results: Stock analysis, Covid-19

\begin{tabular}{|c|c|c|c|c|c|c|}
\hline & \multicolumn{2}{|c|}{ Employment } & \multicolumn{2}{|c|}{ Unemployment } & \multicolumn{2}{|c|}{ NILF } \\
\hline & $\mathrm{w} /$ Occ. & w/o Occ. & $\mathrm{w} /$ Occ. & $\mathrm{w} / \mathrm{o}$ Occ. & w/ Occ. & $\mathrm{w} / \mathrm{o}$ Occ. \\
\hline Spring & $\begin{array}{c}-0.056^{* * *} \\
(0.004)\end{array}$ & $\begin{array}{c}-0.034^{* * *} \\
(0.006)\end{array}$ & $\begin{array}{c}0.052^{* * *} \\
(0.004)\end{array}$ & $\begin{array}{c}0.032^{* * *} \\
(0.006)\end{array}$ & $\begin{array}{c}0.004^{* * *} \\
(0.001)\end{array}$ & $\begin{array}{c}0.002 \\
(0.002)\end{array}$ \\
\hline Summer & $\begin{array}{c}-0.053^{* * *} \\
(0.004)\end{array}$ & $\begin{array}{c}-0.033^{* * *} \\
(0.006)\end{array}$ & $\begin{array}{c}0.050 * * * \\
(0.004)\end{array}$ & $\begin{array}{c}0.032^{* * *} \\
(0.005)\end{array}$ & $\begin{array}{c}0.003^{* *} \\
(0.001)\end{array}$ & $\begin{array}{c}0.001 \\
(0.002)\end{array}$ \\
\hline Fall & $\begin{array}{c}-0.034^{* * *} \\
(0.004)\end{array}$ & $\begin{array}{c}-0.032^{* * *} * \\
(0.005)\end{array}$ & $\begin{array}{c}0.033^{* * *} * \\
(0.003)\end{array}$ & $\begin{array}{c}0.033^{* * *} * \\
(0.005)\end{array}$ & $\begin{array}{c}0.001 \\
(0.001)\end{array}$ & $\begin{array}{l}-0.001 \\
(0.002)\end{array}$ \\
\hline Female & $\begin{array}{c}0.017^{* * *} \\
(0.003)\end{array}$ & $\begin{array}{c}0.013^{* * *} \\
(0.003)\end{array}$ & $\begin{array}{c}-0.016^{* * *} \\
(0.003)\end{array}$ & $\begin{array}{c}-0.012^{* * *} \\
(0.003)\end{array}$ & $\begin{array}{l}-0.001 \\
(0.001)\end{array}$ & $\begin{array}{l}-0.001 \\
(0.001)\end{array}$ \\
\hline Married & $\begin{array}{c}0.032^{* * *} \\
(0.003)\end{array}$ & $\begin{array}{c}0.031^{* * *} \\
(0.003)\end{array}$ & $\begin{array}{c}-0.029^{* * *} \\
(0.002)\end{array}$ & $\begin{array}{c}-0.028^{* * *} \\
(0.003)\end{array}$ & $\begin{array}{c}-0.003^{* * *} \\
(0.001)\end{array}$ & $\begin{array}{c}-0.004^{* * *} \\
(0.001)\end{array}$ \\
\hline Children & $\begin{array}{l}-0.009 \\
(0.007)\end{array}$ & $\begin{array}{c}-0.019^{* *} \\
(0.009)\end{array}$ & $\begin{array}{c}0.007 \\
(0.006)\end{array}$ & $\begin{array}{c}0.019 * * \\
(0.008)\end{array}$ & $\begin{array}{c}0.002 \\
(0.002)\end{array}$ & $\begin{array}{c}0.000 \\
(0.002)\end{array}$ \\
\hline Female*Married & $\begin{array}{c}-0.021^{* * *} \\
(0.004)\end{array}$ & $\begin{array}{c}-0.023^{* * *} \\
(0.004)\end{array}$ & $\begin{array}{c}0.017 * * * \\
(0.003)\end{array}$ & $\begin{array}{c}0.018 * * * \\
(0.004)\end{array}$ & $\begin{array}{c}0.004 * * * \\
(0.001)\end{array}$ & $\begin{array}{c}0.005 * * * \\
(0.002)\end{array}$ \\
\hline Female*Children & $\begin{array}{c}-0.009 \\
(0.008)\end{array}$ & $\begin{array}{c}-0.003 \\
(0.010)\end{array}$ & $\begin{array}{c}0.006 \\
(0.007)\end{array}$ & $\begin{array}{c}-0.002 \\
(0.010)\end{array}$ & $\begin{array}{c}0.002 \\
(0.003)\end{array}$ & $\begin{array}{c}0.005 \\
(0.003)\end{array}$ \\
\hline Married*Children & $\begin{array}{c}0.011 \\
(0.007)\end{array}$ & $\begin{array}{c}0.022^{* *} \\
(0.009)\end{array}$ & $\begin{array}{l}-0.007 \\
(0.006)\end{array}$ & $\begin{array}{c}-0.020^{* *} \\
(0.009)\end{array}$ & $\begin{array}{l}-0.004 \\
(0.002)\end{array}$ & $\begin{array}{c}-0.001 \\
(0.003)\end{array}$ \\
\hline Female*Married $^{*}$ Children & $\begin{array}{l}-0.001 \\
(0.008)\end{array}$ & $\begin{array}{l}-0.006 \\
(0.011)\end{array}$ & $\begin{array}{l}-0.000 \\
(0.008)\end{array}$ & $\begin{array}{c}0.009 \\
(0.010)\end{array}$ & $\begin{array}{c}0.001 \\
(0.003)\end{array}$ & $\begin{array}{l}-0.003 \\
(0.003)\end{array}$ \\
\hline Female*Spring & $\begin{array}{c}-0.018^{* * *} \\
(0.005)\end{array}$ & $\begin{array}{c}-0.016^{* * *} \\
(0.006)\end{array}$ & $\begin{array}{c}0.016^{* * * *} \\
(0.005)\end{array}$ & $\begin{array}{c}0.016^{* * *} \\
(0.006)\end{array}$ & $\begin{array}{c}0.002 \\
(0.002)\end{array}$ & $\begin{array}{c}0.000 \\
(0.002)\end{array}$ \\
\hline Female*Summer & $\begin{array}{c}-0.011^{* *} \\
(0.005)\end{array}$ & $\begin{array}{c}-0.011^{*} \\
(0.006)\end{array}$ & $\begin{array}{c}0.010^{* *} \\
(0.004)\end{array}$ & $\begin{array}{l}0.009^{*} \\
(0.006)\end{array}$ & $\begin{array}{c}0.001 \\
(0.002)\end{array}$ & $\begin{array}{c}0.001 \\
(0.002)\end{array}$ \\
\hline Female*Fall & $\begin{array}{c}-0.007^{*} \\
(0.004)\end{array}$ & $\begin{array}{c}-0.011^{* *} \\
(0.005)\end{array}$ & $\begin{array}{c}0.004 \\
(0.004)\end{array}$ & $\begin{array}{c}0.007 \\
(0.005)\end{array}$ & $\begin{array}{l}0.003^{*} \\
(0.001)\end{array}$ & $\begin{array}{c}0.005 * * * \\
(0.002)\end{array}$ \\
\hline Married*Spring & $\begin{array}{c}0.033^{* * *} * \\
(0.005)\end{array}$ & $\begin{array}{c}0.021^{* * * *} \\
(0.005)\end{array}$ & $\begin{array}{c}-0.029 * * * \\
(0.004)\end{array}$ & $\begin{array}{c}-0.019^{* * *} \\
(0.005)\end{array}$ & $\begin{array}{c}-0.005^{* * *} \\
(0.001)\end{array}$ & $\begin{array}{l}-0.002 \\
(0.002)\end{array}$ \\
\hline Married*Summer & $\begin{array}{c}0.027 * * * \\
(0.004)\end{array}$ & $\begin{array}{c}0.013^{* *} \\
(0.005)\end{array}$ & $\begin{array}{c}-0.024^{* * *} \\
(0.004)\end{array}$ & $\begin{array}{c}-0.013^{* * *} \\
(0.005)\end{array}$ & $\begin{array}{l}-0.002 \\
(0.001)\end{array}$ & $\begin{array}{l}-0.000 \\
(0.002)\end{array}$ \\
\hline Married ${ }^{*}$ Fall & $\begin{array}{c}0.021^{* * *} \\
(0.004)\end{array}$ & $\begin{array}{c}0.014 * * * \\
(0.004)\end{array}$ & $\begin{array}{c}-0.021 * * * \\
(0.004)\end{array}$ & $\begin{array}{c}-0.016 * * * \\
(0.004)\end{array}$ & $\begin{array}{l}-0.000 \\
(0.001)\end{array}$ & $\begin{array}{c}0.002 \\
(0.001)\end{array}$ \\
\hline Children*Spring & $\begin{array}{c}0.004 \\
(0.011)\end{array}$ & $\begin{array}{c}0.015 \\
(0.013)\end{array}$ & $\begin{array}{c}0.002 \\
(0.010)\end{array}$ & $\begin{array}{l}-0.010 \\
(0.013)\end{array}$ & $\begin{array}{l}-0.006^{*} \\
(0.003)\end{array}$ & $\begin{array}{l}-0.005 \\
(0.004)\end{array}$ \\
\hline Children*Summer & $\begin{array}{c}0.008 \\
(0.010)\end{array}$ & $\begin{array}{c}0.006 \\
(0.013)\end{array}$ & $\begin{array}{c}0.001 \\
(0.010)\end{array}$ & $\begin{array}{c}0.000 \\
(0.013)\end{array}$ & $\begin{array}{c}-0.008 * * * \\
(0.003)\end{array}$ & $\begin{array}{c}-0.006 * \\
(0.003)\end{array}$ \\
\hline Children*Fall & $\begin{array}{c}0.020^{* *} \\
(0.009)\end{array}$ & $\begin{array}{c}0.024^{* *} \\
(0.011)\end{array}$ & $\begin{array}{c}-0.017^{* *} \\
(0.008)\end{array}$ & $\begin{array}{c}-0.025^{* *} \\
(0.011)\end{array}$ & $\begin{array}{c}-0.003 \\
(0.003)\end{array}$ & $\begin{array}{c}0.000 \\
(0.003)\end{array}$ \\
\hline Female*Married ${ }^{*}$ Spring & $\begin{array}{c}-0.015^{* *} \\
(0.006)\end{array}$ & $\begin{array}{l}-0.008 \\
(0.008)\end{array}$ & $\begin{array}{c}0.014^{* *} \\
(0.006)\end{array}$ & $\begin{array}{c}0.009 \\
(0.007)\end{array}$ & $\begin{array}{c}0.001 \\
(0.002)\end{array}$ & $\begin{array}{l}-0.001 \\
(0.002)\end{array}$ \\
\hline Female*Married*Summer & $\begin{array}{c}-0.023^{* * *} \\
(0.006)\end{array}$ & $\begin{array}{l}-0.008 \\
(0.007)\end{array}$ & $\begin{array}{c}0.022^{* * *} \\
(0.006)\end{array}$ & $\begin{array}{c}0.011 \\
(0.007)\end{array}$ & $\begin{array}{c}0.002 \\
(0.002)\end{array}$ & $\begin{array}{l}-0.002 \\
(0.002)\end{array}$ \\
\hline Female*Married ${ }^{*}$ Fall & $\begin{array}{l}-0.004 \\
(0.005)\end{array}$ & $\begin{array}{c}0.003 \\
(0.006)\end{array}$ & $\begin{array}{c}0.006 \\
(0.005)\end{array}$ & $\begin{array}{c}0.002 \\
(0.006)\end{array}$ & $\begin{array}{l}-0.002 \\
(0.002)\end{array}$ & $\begin{array}{c}-0.005^{* *} \\
(0.002)\end{array}$ \\
\hline Female*Children*Spring & $\begin{array}{c}0.008 \\
(0.013)\end{array}$ & $\begin{array}{c}0.005 \\
(0.016)\end{array}$ & $\begin{array}{l}-0.015 \\
(0.012)\end{array}$ & $\begin{array}{l}-0.011 \\
(0.016)\end{array}$ & $\begin{array}{c}0.007 \\
(0.004)\end{array}$ & $\begin{array}{c}0.006 \\
(0.005)\end{array}$ \\
\hline Female*Children*Summer & $\begin{array}{l}-0.014 \\
(0.013)\end{array}$ & $\begin{array}{l}-0.003 \\
(0.016)\end{array}$ & $\begin{array}{c}0.005 \\
(0.012)\end{array}$ & $\begin{array}{l}-0.002 \\
(0.016)\end{array}$ & $\begin{array}{c}0.009^{* *} \\
(0.004)\end{array}$ & $\begin{array}{c}0.005 \\
(0.005)\end{array}$ \\
\hline Female*Children*Fall & $\begin{array}{l}-0.018^{*} \\
(0.011)\end{array}$ & $\begin{array}{l}-0.015 \\
(0.014)\end{array}$ & $\begin{array}{c}0.016 \\
(0.010)\end{array}$ & $\begin{array}{c}0.017 \\
(0.013)\end{array}$ & $\begin{array}{c}0.003 \\
(0.004)\end{array}$ & $\begin{array}{l}-0.002 \\
(0.005)\end{array}$ \\
\hline Married*Children*Spring & $\begin{array}{l}-0.011 \\
(0.011)\end{array}$ & $\begin{array}{c}-0.026^{*} \\
(0.014)\end{array}$ & $\begin{array}{c}0.004 \\
(0.011)\end{array}$ & $\begin{array}{c}0.021 \\
(0.014)\end{array}$ & $\begin{array}{l}0.007^{*} \\
(0.004)\end{array}$ & $\begin{array}{c}0.005 \\
(0.004)\end{array}$ \\
\hline Married*Children*Summer & $\begin{array}{l}-0.007 \\
(0.011)\end{array}$ & $\begin{array}{l}-0.004 \\
(0.014)\end{array}$ & $\begin{array}{l}-0.000 \\
(0.010)\end{array}$ & $\begin{array}{l}-0.000 \\
(0.014)\end{array}$ & $\begin{array}{c}0.008 * * \\
(0.003)\end{array}$ & $\begin{array}{c}0.005 \\
(0.003)\end{array}$ \\
\hline Married ${ }^{*}$ Children ${ }^{*}$ Fall & $\begin{array}{c}-0.023^{* *} * \\
(0.009)\end{array}$ & $\begin{array}{c}-0.027^{* *} \\
(0.012)\end{array}$ & $\begin{array}{c}0.020 * * \\
(0.009)\end{array}$ & $\begin{array}{c}0.029 * * \\
(0.012)\end{array}$ & $\begin{array}{c}0.003 \\
(0.003)\end{array}$ & $\begin{array}{l}-0.002 \\
(0.004)\end{array}$ \\
\hline Female*Married*Children*Spring & $\begin{array}{l}-0.017 \\
(0.014)\end{array}$ & $\begin{array}{l}-0.010 \\
(0.018)\end{array}$ & $\begin{array}{l}0.023^{*} \\
(0.014)\end{array}$ & $\begin{array}{c}0.014 \\
(0.017)\end{array}$ & $\begin{array}{l}-0.006 \\
(0.005)\end{array}$ & $\begin{array}{l}-0.004 \\
(0.005)\end{array}$ \\
\hline Female*Married*Children*Summer & $\begin{array}{c}0.013 \\
(0.014)\end{array}$ & $\begin{array}{c}0.002 \\
(0.018)\end{array}$ & $\begin{array}{l}-0.007 \\
(0.013)\end{array}$ & $\begin{array}{l}-0.002 \\
(0.017)\end{array}$ & $\begin{array}{l}-0.007 \\
(0.005)\end{array}$ & $\begin{array}{l}-0.001 \\
(0.005)\end{array}$ \\
\hline Female*Married*Children*Fall & $\begin{array}{l}0.023^{*} \\
(0.012)\end{array}$ & $\begin{array}{c}0.017 \\
(0.015)\end{array}$ & $\begin{array}{c}-0.023^{* *} \\
(0.011)\end{array}$ & $\begin{array}{l}-0.023 \\
(0.014)\end{array}$ & $\begin{array}{l}-0.000 \\
(0.004)\end{array}$ & $\begin{array}{l}0.006 \\
(0.005)\end{array}$ \\
\hline Constant & $\begin{array}{c}0.958^{* * *} \\
(0.002)\end{array}$ & $\begin{array}{c}0.965^{* * *} \\
(0.003)\end{array}$ & $\begin{array}{c}0.039 * * * \\
(0.002)\end{array}$ & $\begin{array}{c}0.032^{* * *} \\
(0.003)\end{array}$ & $\begin{array}{c}0.004^{* * *} \\
(0.001)\end{array}$ & $\begin{array}{c}0.003^{* * *} \\
(0.001)\end{array}$ \\
\hline Observations & 354,794 & 354,794 & 354,794 & 354,794 & 354,794 & 354,794 \\
\hline $\mathrm{R}$-squared & 0.029 & 0.057 & 0.027 & 0.054 & 0.003 & 0.004 \\
\hline
\end{tabular}

Robust standard errors in parentheses

*** $p<0.01, * * p<0.05, * p<0.1$ 
Table 11: Regression Results: Flow analysis, Covid-19

\begin{tabular}{|c|c|c|c|c|c|c|}
\hline \multirow{3}{*}{ Spring } & \multicolumn{2}{|c|}{$\mathrm{E}$ to $\mathrm{N}$} & \multicolumn{2}{|c|}{$\mathrm{U}$ to $\mathrm{N}$} & \multicolumn{2}{|c|}{$\mathrm{E}$ to $\mathrm{U}$} \\
\hline & $\mathrm{w} /$ Occ. & w/o Occ. & w/ Occ. & w/o Occ. & $\mathrm{w} / \mathrm{Occ}$. & w/o Occ. \\
\hline & $\begin{array}{c}0.003^{* * *} \\
(0.001)\end{array}$ & $\begin{array}{c}0.003 * * \\
(0.001)\end{array}$ & $\begin{array}{c}0.001 \\
(0.000)\end{array}$ & $\begin{array}{c}0.000 \\
(0.001)\end{array}$ & $\begin{array}{c}0.027^{* * *} \\
(0.003)\end{array}$ & $\begin{array}{c}0.016 * * * \\
(0.005)\end{array}$ \\
\hline Summer & $\begin{array}{c}0.001 \\
(0.001)\end{array}$ & $\begin{array}{c}0.000 \\
(0.001)\end{array}$ & $\begin{array}{c}0.002^{* * *} \\
(0.001)\end{array}$ & $\begin{array}{c}0.001 \\
(0.001)\end{array}$ & $\begin{array}{c}0.014^{* * *} \\
(0.003)\end{array}$ & $\begin{array}{c}0.011^{* * *} \\
(0.004)\end{array}$ \\
\hline Fall & $\begin{array}{l}0.002^{*} \\
(0.001)\end{array}$ & $\begin{array}{c}0.001 \\
(0.001)\end{array}$ & $\begin{array}{c}0.001 * * \\
(0.001)\end{array}$ & $\begin{array}{c}0.001 \\
(0.001)\end{array}$ & $\begin{array}{c}0.002 \\
(0.002)\end{array}$ & $\begin{array}{c}0.008 * * \\
(0.004)\end{array}$ \\
\hline Female & $\begin{array}{l}-0.000 \\
(0.001)\end{array}$ & $\begin{array}{l}-0.001 \\
(0.001)\end{array}$ & $\begin{array}{l}-0.000 \\
(0.000)\end{array}$ & $\begin{array}{l}-0.000 \\
(0.000)\end{array}$ & $\begin{array}{c}-0.006 * * * \\
(0.002)\end{array}$ & $\begin{array}{l}-0.003 \\
(0.002)\end{array}$ \\
\hline Married & $\begin{array}{l}-0.000 \\
(0.001)\end{array}$ & $\begin{array}{l}-0.001 \\
(0.001)\end{array}$ & $\begin{array}{c}0.000 \\
(0.000)\end{array}$ & $\begin{array}{l}-0.000 \\
(0.000)\end{array}$ & $\begin{array}{c}-0.007 * * * \\
(0.002)\end{array}$ & $\begin{array}{c}-0.006 * * * \\
(0.002)\end{array}$ \\
\hline Children & $\begin{array}{c}0.001 \\
(0.002)\end{array}$ & $\begin{array}{c}0.002 \\
(0.003)\end{array}$ & $\begin{array}{c}0.001 \\
(0.001)\end{array}$ & $\begin{array}{c}0.001 \\
(0.001)\end{array}$ & $\begin{array}{c}0.002 \\
(0.005)\end{array}$ & $\begin{array}{c}0.008 \\
(0.007)\end{array}$ \\
\hline Female*Married & $\begin{array}{c}0.001 \\
(0.001)\end{array}$ & $\begin{array}{c}0.001 \\
(0.001)\end{array}$ & $\begin{array}{c}0.000 \\
(0.000)\end{array}$ & $\begin{array}{c}0.001 \\
(0.000)\end{array}$ & $\begin{array}{c}0.004 \\
(0.003)\end{array}$ & $\begin{array}{c}0.003 \\
(0.003)\end{array}$ \\
\hline Female*Children & $\begin{array}{c}0.001 \\
(0.002)\end{array}$ & $\begin{array}{l}-0.000 \\
(0.003)\end{array}$ & $\begin{array}{c}0.001 \\
(0.001)\end{array}$ & $\begin{array}{c}0.001 \\
(0.002)\end{array}$ & $\begin{array}{c}0.002 \\
(0.006)\end{array}$ & $\begin{array}{l}-0.005 \\
(0.008)\end{array}$ \\
\hline Married*Children & $\begin{array}{l}-0.001 \\
(0.002)\end{array}$ & $\begin{array}{l}-0.002 \\
(0.003)\end{array}$ & $\begin{array}{l}-0.001 \\
(0.001)\end{array}$ & $\begin{array}{l}-0.001 \\
(0.001)\end{array}$ & $\begin{array}{l}-0.001 \\
(0.005)\end{array}$ & $\begin{array}{l}-0.008 \\
(0.007)\end{array}$ \\
\hline Female*Married*Children & $\begin{array}{l}-0.000 \\
(0.002)\end{array}$ & $\begin{array}{c}0.001 \\
(0.003)\end{array}$ & $\begin{array}{l}-0.001 \\
(0.001)\end{array}$ & $\begin{array}{l}-0.001 \\
(0.002)\end{array}$ & $\begin{array}{c}0.002 \\
(0.006)\end{array}$ & $\begin{array}{c}0.008 \\
(0.008)\end{array}$ \\
\hline Female*Spring & $\begin{array}{c}0.000 \\
(0.001)\end{array}$ & $\begin{array}{l}-0.001 \\
(0.002)\end{array}$ & $\begin{array}{c}0.001 \\
(0.001)\end{array}$ & $\begin{array}{c}0.000 \\
(0.001)\end{array}$ & $\begin{array}{c}0.011 * * * \\
(0.004)\end{array}$ & $\begin{array}{c}0.006 \\
(0.005)\end{array}$ \\
\hline Female*Summer & $\begin{array}{c}0.001 \\
(0.001)\end{array}$ & $\begin{array}{l}0.003^{*} \\
(0.001)\end{array}$ & $\begin{array}{c}0.001 \\
(0.001)\end{array}$ & $\begin{array}{c}0.001 \\
(0.001)\end{array}$ & $\begin{array}{c}0.007 * * \\
(0.003)\end{array}$ & $\begin{array}{c}0.001 \\
(0.004)\end{array}$ \\
\hline Female*Fall & $\begin{array}{c}0.000 \\
(0.001)\end{array}$ & $\begin{array}{c}0.001 \\
(0.001)\end{array}$ & $\begin{array}{l}-0.000 \\
(0.001)\end{array}$ & $\begin{array}{c}0.000 \\
(0.001)\end{array}$ & $\begin{array}{c}0.004 \\
(0.003)\end{array}$ & $\begin{array}{c}0.001 \\
(0.003)\end{array}$ \\
\hline Married ${ }^{*}$ Spring & $\begin{array}{c}-0.004 * * * \\
(0.001)\end{array}$ & $\begin{array}{c}-0.003 * * \\
(0.001)\end{array}$ & $\begin{array}{l}-0.000 \\
(0.001)\end{array}$ & $\begin{array}{l}-0.000 \\
(0.001)\end{array}$ & $\begin{array}{c}-0.012 * * * \\
(0.004)\end{array}$ & $\begin{array}{c}-0.008^{*} \\
(0.004)\end{array}$ \\
\hline Married*Summer & $\begin{array}{l}-0.001 \\
(0.001)\end{array}$ & $\begin{array}{c}0.001 \\
(0.001)\end{array}$ & $\begin{array}{c}-0.002^{* *} \\
(0.001)\end{array}$ & $\begin{array}{l}-0.001^{*} \\
(0.001)\end{array}$ & $\begin{array}{l}-0.002 \\
(0.003)\end{array}$ & $\begin{array}{l}-0.001 \\
(0.004)\end{array}$ \\
\hline Married ${ }^{*}$ Fall & $\begin{array}{l}-0.000 \\
(0.001)\end{array}$ & $\begin{array}{c}0.001 \\
(0.001)\end{array}$ & $\begin{array}{l}-0.001 \\
(0.001)\end{array}$ & $\begin{array}{l}-0.000 \\
(0.001)\end{array}$ & $\begin{array}{c}0.001 \\
(0.003)\end{array}$ & $\begin{array}{l}-0.001 \\
(0.003)\end{array}$ \\
\hline Children*Spring & $\begin{array}{l}-0.004 \\
(0.002)\end{array}$ & $\begin{array}{c}-0.007^{* *} \\
(0.003)\end{array}$ & $\begin{array}{c}0.000 \\
(0.002)\end{array}$ & $\begin{array}{l}-0.001 \\
(0.002)\end{array}$ & $\begin{array}{l}-0.009 \\
(0.008)\end{array}$ & $\begin{array}{l}-0.018^{*} \\
(0.011)\end{array}$ \\
\hline Children*Summer & $\begin{array}{l}-0.003^{*} \\
(0.002)\end{array}$ & $\begin{array}{l}-0.005 \\
(0.003)\end{array}$ & $\begin{array}{c}0.000 \\
(0.002)\end{array}$ & $\begin{array}{c}0.001 \\
(0.002)\end{array}$ & $\begin{array}{c}0.000 \\
(0.007)\end{array}$ & $\begin{array}{c}0.000 \\
(0.010)\end{array}$ \\
\hline Children*Fall & $\begin{array}{l}-0.002 \\
(0.002)\end{array}$ & $\begin{array}{c}-0.003 \\
(0.003)\end{array}$ & $\begin{array}{c}-0.001 \\
(0.001)\end{array}$ & $\begin{array}{l}-0.001 \\
(0.002)\end{array}$ & $\begin{array}{c}0.000 \\
(0.006)\end{array}$ & $\begin{array}{l}-0.004 \\
(0.009)\end{array}$ \\
\hline Female*Married $^{*}$ Spring & $\begin{array}{c}0.002 \\
(0.002)\end{array}$ & $\begin{array}{c}0.002 \\
(0.002)\end{array}$ & $\begin{array}{l}-0.000 \\
(0.001)\end{array}$ & $\begin{array}{l}-0.000 \\
(0.001)\end{array}$ & $\begin{array}{c}0.006 \\
(0.005)\end{array}$ & $\begin{array}{c}0.007 \\
(0.006)\end{array}$ \\
\hline Female*Married ${ }^{*}$ Summer & $\begin{array}{l}-0.000 \\
(0.001)\end{array}$ & $\begin{array}{l}-0.002 \\
(0.002)\end{array}$ & $\begin{array}{l}-0.000 \\
(0.001)\end{array}$ & $\begin{array}{l}-0.001 \\
(0.001)\end{array}$ & $\begin{array}{c}0.007 * \\
(0.004)\end{array}$ & $\begin{array}{c}0.005 \\
(0.005)\end{array}$ \\
\hline Female*Married*Fall & $\begin{array}{l}-0.001 \\
(0.001)\end{array}$ & $\begin{array}{l}-0.001 \\
(0.002)\end{array}$ & $\begin{array}{c}0.001 \\
(0.001)\end{array}$ & $\begin{array}{c}0.000 \\
(0.001)\end{array}$ & $\begin{array}{l}-0.001 \\
(0.004)\end{array}$ & $\begin{array}{l}-0.000 \\
(0.004)\end{array}$ \\
\hline Female*Children*Spring & $\begin{array}{c}0.004 \\
(0.003)\end{array}$ & $\begin{array}{c}0.008 * * \\
(0.004)\end{array}$ & $\begin{array}{l}-0.001 \\
(0.002)\end{array}$ & $\begin{array}{c}0.001 \\
(0.002)\end{array}$ & $\begin{array}{c}0.008 \\
(0.010)\end{array}$ & $\begin{array}{c}0.015 \\
(0.013)\end{array}$ \\
\hline Female*Children*Summer & $\begin{array}{l}0.004^{*} \\
(0.003)\end{array}$ & $\begin{array}{c}0.005 \\
(0.003)\end{array}$ & $\begin{array}{l}-0.003 \\
(0.002)\end{array}$ & $\begin{array}{c}-0.004 \\
(0.003)\end{array}$ & $\begin{array}{c}0.009 \\
(0.009)\end{array}$ & $\begin{array}{c}0.013 \\
(0.012)\end{array}$ \\
\hline Female*Children*Fall & $\begin{array}{c}0.002 \\
(0.003)\end{array}$ & $\begin{array}{c}0.002 \\
(0.004)\end{array}$ & $\begin{array}{c}0.001 \\
(0.002)\end{array}$ & $\begin{array}{c}0.000 \\
(0.003)\end{array}$ & $\begin{array}{c}0.003 \\
(0.008)\end{array}$ & $\begin{array}{c}0.007 \\
(0.010)\end{array}$ \\
\hline Married*Children*Spring & $\begin{array}{l}0.005^{*} \\
(0.003)\end{array}$ & $\begin{array}{c}0.008^{* *} * \\
(0.003)\end{array}$ & $\begin{array}{l}-0.000 \\
(0.002)\end{array}$ & $\begin{array}{c}0.001 \\
(0.002)\end{array}$ & $\begin{array}{c}0.012 \\
(0.009)\end{array}$ & $\begin{array}{c}0.024^{* *} \\
(0.011)\end{array}$ \\
\hline Married*Children*Summer & $\begin{array}{c}0.003 \\
(0.002)\end{array}$ & $\begin{array}{c}0.003 \\
(0.003)\end{array}$ & $\begin{array}{l}-0.001 \\
(0.002)\end{array}$ & $\begin{array}{l}-0.001 \\
(0.002)\end{array}$ & $\begin{array}{c}0.003 \\
(0.007)\end{array}$ & $\begin{array}{c}0.000 \\
(0.011)\end{array}$ \\
\hline Married*Children*Fall & $\begin{array}{c}0.002 \\
(0.002)\end{array}$ & $\begin{array}{c}0.002 \\
(0.003)\end{array}$ & $\begin{array}{c}0.001 \\
(0.002)\end{array}$ & $\begin{array}{c}0.000 \\
(0.002)\end{array}$ & $\begin{array}{c}0.000 \\
(0.007)\end{array}$ & $\begin{array}{c}0.005 \\
(0.009)\end{array}$ \\
\hline Female*Married ${ }^{*}$ Children*Spring & $\begin{array}{c}-0.003 \\
(0.004)\end{array}$ & $\begin{array}{c}-0.008^{*} \\
(0.004)\end{array}$ & $\begin{array}{c}0.001 \\
(0.002)\end{array}$ & $\begin{array}{l}-0.000 \\
(0.003)\end{array}$ & $\begin{array}{l}-0.004 \\
(0.012)\end{array}$ & $\begin{array}{l}-0.014 \\
(0.014)\end{array}$ \\
\hline Female*Married*Children*Summer & $\begin{array}{l}-0.004 \\
(0.003)\end{array}$ & $\begin{array}{l}-0.004 \\
(0.004)\end{array}$ & $\begin{array}{l}0.004^{*} \\
(0.002)\end{array}$ & $\begin{array}{l}0.006^{*} \\
(0.003)\end{array}$ & $\begin{array}{l}-0.013 \\
(0.010)\end{array}$ & $\begin{array}{l}-0.016 \\
(0.013)\end{array}$ \\
\hline Female*Married*Children*Fall & $\begin{array}{l}-0.000 \\
(0.003)\end{array}$ & $\begin{array}{l}-0.001 \\
(0.004)\end{array}$ & $\begin{array}{l}-0.002 \\
(0.002)\end{array}$ & $\begin{array}{c}0.000 \\
(0.003)\end{array}$ & $\begin{array}{l}-0.003 \\
(0.008)\end{array}$ & $\begin{array}{l}-0.006 \\
(0.011)\end{array}$ \\
\hline Constant & $\begin{array}{l}0.001^{*} \\
(0.001)\end{array}$ & $\begin{array}{c}0.001 \\
(0.001)\end{array}$ & $\begin{array}{l}-0.000 \\
(0.000)\end{array}$ & $\begin{array}{c}0.000 \\
(0.000)\end{array}$ & $\begin{array}{c}0.013^{* * *} \\
(0.002)\end{array}$ & $\begin{array}{c}0.009 * * * \\
(0.003)\end{array}$ \\
\hline Observations & 224,512 & 224,512 & 224,512 & 224,512 & 224,512 & 224,512 \\
\hline R-squared & 0.002 & 0.003 & 0.001 & 0.001 & 0.017 & 0.030 \\
\hline
\end{tabular}

Robust standard errors in parentheses

*** $p<0.01, * * p<0.05, * p<0.1$ 
Table 12: Regression Results: Flow analysis, Covid-19 (Continued)

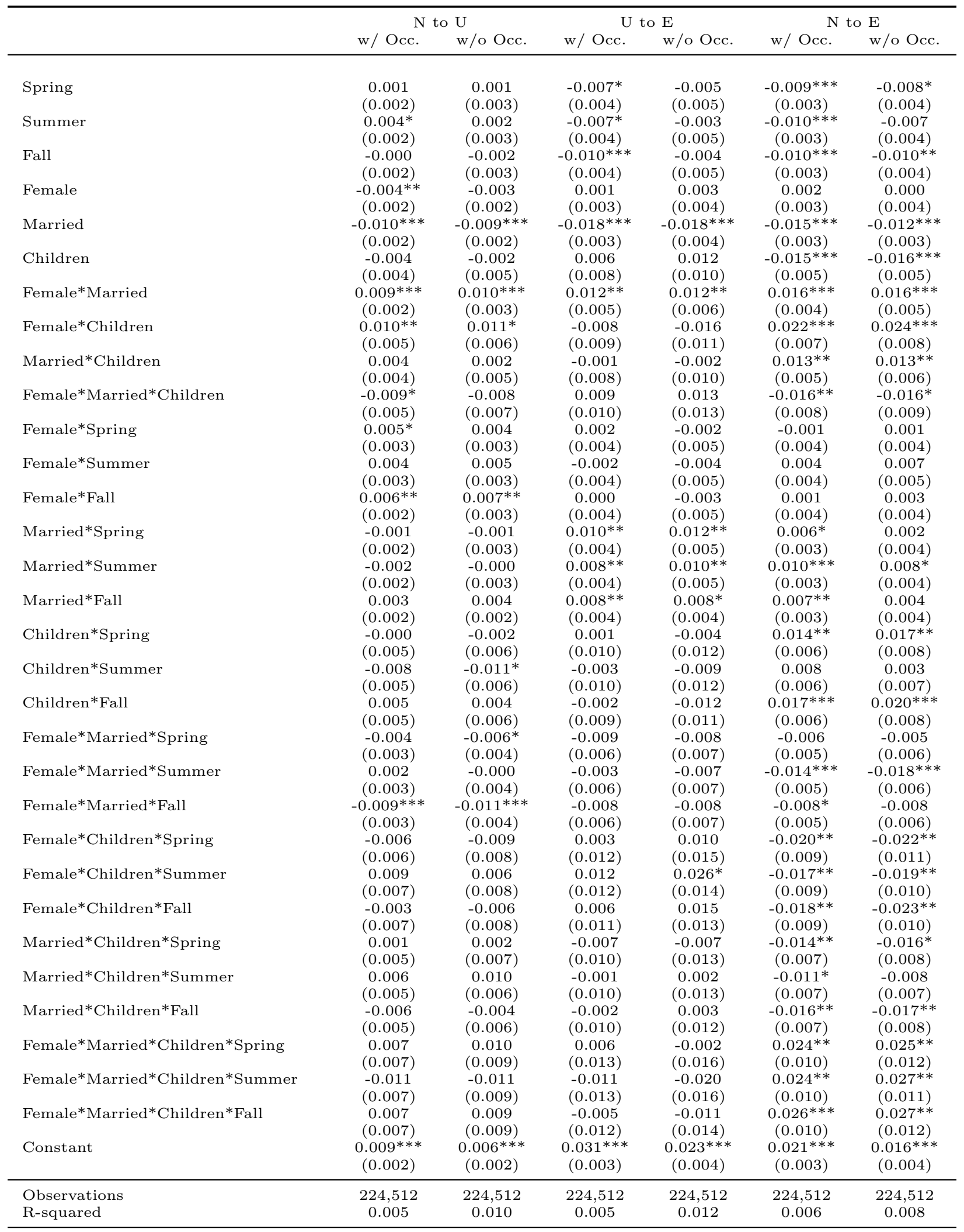

Robust standard errors in parentheses

*** $p<0.01, * * p<0.05, * p<0.1$ 
Table 13: Regression Results: Stock analysis, Great Recession

\begin{tabular}{|c|c|c|c|c|c|c|}
\hline & \multicolumn{2}{|c|}{ Employment } & \multicolumn{2}{|c|}{ Unemployment } & \multicolumn{2}{|c|}{ NILF } \\
\hline & $\mathrm{w} /$ Occ. & w/o Occ. & $\mathrm{w} /$ Occ. & $\mathrm{w} / \mathrm{o}$ Occ. & $\mathrm{w} /$ Occ. & $\mathrm{w} / \mathrm{o}$ Occ. \\
\hline Spring & $\begin{array}{c}-0.023^{* * *} \\
(0.001)\end{array}$ & $\begin{array}{c}-0.024^{* * *} \\
(0.002)\end{array}$ & $\begin{array}{c}0.023^{* * *} \\
(0.001)\end{array}$ & $\begin{array}{c}0.024^{* * *} \\
(0.002)\end{array}$ & $\begin{array}{c}0.000 \\
(0.000)\end{array}$ & $\begin{array}{c}0.000 \\
(0.001)\end{array}$ \\
\hline Summer & $\begin{array}{c}-0.049 * * * \\
(0.001)\end{array}$ & $\begin{array}{c}-0.045^{* * *} \\
(0.002)\end{array}$ & $\begin{array}{c}0.049 * * * \\
(0.001)\end{array}$ & $\begin{array}{c}0.045^{* * *} \\
(0.002)\end{array}$ & $\begin{array}{l}-0.000 \\
(0.000)\end{array}$ & $\begin{array}{l}-0.000 \\
(0.001)\end{array}$ \\
\hline Fall & $\begin{array}{c}-0.033^{*} * * \\
(0.001)\end{array}$ & $\begin{array}{c}-0.028 * * * \\
(0.002)\end{array}$ & $\begin{array}{c}0.033^{* * *} * \\
(0.001)\end{array}$ & $\begin{array}{c}0.029 * * * \\
(0.002)\end{array}$ & $\begin{array}{l}-0.000 \\
(0.000)\end{array}$ & $\begin{array}{l}-0.001 \\
(0.001)\end{array}$ \\
\hline Female & $\begin{array}{c}0.005^{* * *} \\
(0.001)\end{array}$ & $\begin{array}{l}-0.000 \\
(0.002)\end{array}$ & $\begin{array}{c}-0.006^{* * *} \\
(0.001)\end{array}$ & $\begin{array}{l}-0.001 \\
(0.001)\end{array}$ & $\begin{array}{c}0.001^{* *} \\
(0.000)\end{array}$ & $\begin{array}{c}0.001 * * \\
(0.001)\end{array}$ \\
\hline Married & $\begin{array}{c}0.032^{* * *} \\
(0.001)\end{array}$ & $\begin{array}{c}0.030^{* * *} \\
(0.001)\end{array}$ & $\begin{array}{c}-0.030^{* * *} \\
(0.001)\end{array}$ & $\begin{array}{c}-0.028^{* * *} \\
(0.001)\end{array}$ & $\begin{array}{c}-0.002^{* * *} \\
(0.000)\end{array}$ & $\begin{array}{c}-0.002^{* * *} \\
(0.000)\end{array}$ \\
\hline Children & $\begin{array}{c}0.004 \\
(0.003)\end{array}$ & $\begin{array}{l}0.006^{*} \\
(0.003)\end{array}$ & $\begin{array}{l}-0.002 \\
(0.003)\end{array}$ & $\begin{array}{l}-0.003 \\
(0.003)\end{array}$ & $\begin{array}{c}-0.002^{* * *} \\
(0.001)\end{array}$ & $\begin{array}{c}-0.002 * * \\
(0.001)\end{array}$ \\
\hline Female*Married & $\begin{array}{c}-0.016 * * * \\
(0.002)\end{array}$ & $\begin{array}{c}-0.014^{* * *} \\
(0.002)\end{array}$ & $\begin{array}{c}0.014^{* * *} \\
(0.002)\end{array}$ & $\begin{array}{c}0.012^{* * *} \\
(0.002)\end{array}$ & $\begin{array}{c}0.002^{* * *} \\
(0.001)\end{array}$ & $\begin{array}{c}0.002^{* * *} \\
(0.001)\end{array}$ \\
\hline Female*Children & $\begin{array}{c}-0.026 * * * \\
(0.003)\end{array}$ & $\begin{array}{c}-0.028 * * * \\
(0.004)\end{array}$ & $\begin{array}{c}0.020^{* * *} \\
(0.003)\end{array}$ & $\begin{array}{c}0.022^{* * *} \\
(0.004)\end{array}$ & $\begin{array}{c}0.006 * * * \\
(0.001)\end{array}$ & $\begin{array}{c}0.006^{* * *} \\
(0.001)\end{array}$ \\
\hline Married*Children & $\begin{array}{c}-0.003 \\
(0.003)\end{array}$ & $\begin{array}{c}-0.003 \\
(0.003)\end{array}$ & $\begin{array}{c}0.002 \\
(0.003)\end{array}$ & $\begin{array}{c}0.003 \\
(0.003)\end{array}$ & $\begin{array}{c}0.001 \\
(0.001)\end{array}$ & $\begin{array}{c}0.001 \\
(0.001)\end{array}$ \\
\hline Female*Married $^{*}$ Children & $\begin{array}{c}0.016 * * * \\
(0.004)\end{array}$ & $\begin{array}{c}0.016^{* * * *} \\
(0.004)\end{array}$ & $\begin{array}{c}-0.015^{* * *} \\
(0.003)\end{array}$ & $\begin{array}{c}-0.015^{* * *} \\
(0.004)\end{array}$ & $\begin{array}{l}-0.001 \\
(0.001)\end{array}$ & $\begin{array}{l}-0.001 \\
(0.001)\end{array}$ \\
\hline Female*Spring & $\begin{array}{c}0.021^{* * *} * \\
(0.002)\end{array}$ & $\begin{array}{c}0.013^{* * *} * \\
(0.002)\end{array}$ & $\begin{array}{c}-0.019 * * * \\
(0.002)\end{array}$ & $\begin{array}{c}-0.012^{* * * *} \\
(0.002)\end{array}$ & $\begin{array}{c}-0.002^{* * *} \\
(0.001)\end{array}$ & $\begin{array}{c}-0.001 * * \\
(0.001)\end{array}$ \\
\hline Female*Summer & $\begin{array}{c}0.027^{* * *} \\
(0.002)\end{array}$ & $\begin{array}{c}0.014^{* * *} \\
(0.002)\end{array}$ & $\begin{array}{c}-0.025^{* * *} \\
(0.002)\end{array}$ & $\begin{array}{c}-0.012^{* * *} \\
(0.002)\end{array}$ & $\begin{array}{c}-0.001^{* * *} \\
(0.001)\end{array}$ & $\begin{array}{c}-0.002^{* *} \\
(0.001)\end{array}$ \\
\hline Female*Fall & $\begin{array}{c}0.015^{* * *} \\
(0.002)\end{array}$ & $\begin{array}{c}0.007^{* * * *} \\
(0.002)\end{array}$ & $\begin{array}{c}-0.015^{* * *} \\
(0.002)\end{array}$ & $\begin{array}{c}-0.007^{* * * *} \\
(0.002)\end{array}$ & $\begin{array}{l}-0.000 \\
(0.001)\end{array}$ & $\begin{array}{l}-0.001 \\
(0.001)\end{array}$ \\
\hline Married*Spring & $\begin{array}{c}0.011^{* * *} \\
(0.001)\end{array}$ & $\begin{array}{c}0.012^{* * * *} \\
(0.002)\end{array}$ & $\begin{array}{c}-0.011^{* * *} \\
(0.001)\end{array}$ & $\begin{array}{c}-0.011^{* * * *} \\
(0.002)\end{array}$ & $\begin{array}{c}-0.001^{*} \\
(0.000)\end{array}$ & $\begin{array}{l}-0.001 \\
(0.001)\end{array}$ \\
\hline Married*Summer & $\begin{array}{c}0.025^{* * *} * \\
(0.002)\end{array}$ & $\begin{array}{c}0.026 * * * \\
(0.002)\end{array}$ & $\begin{array}{c}-0.025^{* * *} \\
(0.002)\end{array}$ & $\begin{array}{c}-0.026^{* * *} \\
(0.002)\end{array}$ & $\begin{array}{l}-0.000 \\
(0.000)\end{array}$ & $\begin{array}{l}-0.000 \\
(0.001)\end{array}$ \\
\hline Married ${ }^{*}$ Fall & $\begin{array}{c}0.020^{* * *} \\
(0.002)\end{array}$ & $\begin{array}{c}0.020 * * * \\
(0.002)\end{array}$ & $\begin{array}{c}-0.020 * * * \\
(0.001)\end{array}$ & $\begin{array}{c}-0.020 * * * \\
(0.002)\end{array}$ & $\begin{array}{c}0.000 \\
(0.000)\end{array}$ & $\begin{array}{c}0.000 \\
(0.001)\end{array}$ \\
\hline Children*Spring & $\begin{array}{c}-0.019 * * * \\
(0.004)\end{array}$ & $\begin{array}{c}-0.018^{* * *} \\
(0.004)\end{array}$ & $\begin{array}{c}0.019 * * * \\
(0.004)\end{array}$ & $\begin{array}{c}0.018^{* * *} \\
(0.004)\end{array}$ & $\begin{array}{c}0.000 \\
(0.001)\end{array}$ & $\begin{array}{c}0.001 \\
(0.001)\end{array}$ \\
\hline Children*Summer & $\begin{array}{c}-0.020^{* * *} \\
(0.004)\end{array}$ & $\begin{array}{c}-0.018 * * * \\
(0.005)\end{array}$ & $\begin{array}{c}0.020^{* * *} \\
(0.004)\end{array}$ & $\begin{array}{c}0.018 * * * \\
(0.004)\end{array}$ & $\begin{array}{c}0.000 \\
(0.001)\end{array}$ & $\begin{array}{c}0.000 \\
(0.001)\end{array}$ \\
\hline Children*Fall & $\begin{array}{c}-0.011^{* * *} \\
(0.004)\end{array}$ & $\begin{array}{c}-0.007^{*} \\
(0.004)\end{array}$ & $\begin{array}{c}0.010^{* * *} \\
(0.004)\end{array}$ & $\begin{array}{c}0.007 \\
(0.004)\end{array}$ & $\begin{array}{c}0.001 \\
(0.001)\end{array}$ & $\begin{array}{c}0.001 \\
(0.001)\end{array}$ \\
\hline Female* Married $^{*}$ Spring & $\begin{array}{c}-0.009 * * * \\
(0.002)\end{array}$ & $\begin{array}{c}-0.011^{* * *} \\
(0.002)\end{array}$ & $\begin{array}{c}0.008 * * * \\
(0.002)\end{array}$ & $\begin{array}{c}0.010 * * * \\
(0.002)\end{array}$ & $\begin{array}{l}0.001 * \\
(0.001)\end{array}$ & $\begin{array}{c}0.001 \\
(0.001)\end{array}$ \\
\hline Female*Married*Summer & $\begin{array}{c}-0.010^{* * *} \\
(0.002)\end{array}$ & $\begin{array}{c}-0.012^{* * *} \\
(0.003)\end{array}$ & $\begin{array}{c}0.010^{* * *} \\
(0.002)\end{array}$ & $\begin{array}{c}0.012^{* * *} \\
(0.003)\end{array}$ & $\begin{array}{c}0.001 \\
(0.001)\end{array}$ & $\begin{array}{c}0.001 \\
(0.001)\end{array}$ \\
\hline Female*Married ${ }^{*}$ Fall & $\begin{array}{c}-0.009^{* * *} \\
(0.002)\end{array}$ & $\begin{array}{c}-0.009 * * * \\
(0.003)\end{array}$ & $\begin{array}{c}0.009^{* * *} \\
(0.002)\end{array}$ & $\begin{array}{c}0.009^{* * *} \\
(0.002)\end{array}$ & $\begin{array}{c}0.000 \\
(0.001)\end{array}$ & $\begin{array}{l}-0.000 \\
(0.001)\end{array}$ \\
\hline Female*Children*Spring & $\begin{array}{c}0.010 * * \\
(0.004)\end{array}$ & $\begin{array}{c}0.006 \\
(0.005)\end{array}$ & $\begin{array}{c}-0.010 * * \\
(0.004)\end{array}$ & $\begin{array}{l}-0.006 \\
(0.005)\end{array}$ & $\begin{array}{l}-0.000 \\
(0.001)\end{array}$ & $\begin{array}{l}-0.000 \\
(0.002)\end{array}$ \\
\hline Female*Children*Summer & $\begin{array}{c}0.002 \\
(0.005)\end{array}$ & $\begin{array}{l}-0.002 \\
(0.006)\end{array}$ & $\begin{array}{l}-0.001 \\
(0.005)\end{array}$ & $\begin{array}{c}0.003 \\
(0.005)\end{array}$ & $\begin{array}{l}-0.001 \\
(0.001)\end{array}$ & $\begin{array}{l}-0.000 \\
(0.001)\end{array}$ \\
\hline Female*Children*Fall & $\begin{array}{c}-0.009^{* *} \\
(0.005)\end{array}$ & $\begin{array}{c}-0.016^{* * *} \\
(0.005)\end{array}$ & $\begin{array}{c}0.012^{* * *} \\
(0.004)\end{array}$ & $\begin{array}{c}0.019^{* * *} \\
(0.005)\end{array}$ & $\begin{array}{c}-0.003^{* * *} \\
(0.001)\end{array}$ & $\begin{array}{c}-0.003^{* *} \\
(0.001)\end{array}$ \\
\hline Married*Children*Spring & $\begin{array}{c}0.021^{* * *} \\
(0.004)\end{array}$ & $\begin{array}{c}0.021^{* * *} \\
(0.005)\end{array}$ & $\begin{array}{c}-0.021^{* * *} \\
(0.004)\end{array}$ & $\begin{array}{c}-0.021^{* * *} \\
(0.004)\end{array}$ & $\begin{array}{c}0.000 \\
(0.001)\end{array}$ & $\begin{array}{l}-0.000 \\
(0.001)\end{array}$ \\
\hline Married*Children*Summer & $\begin{array}{c}0.022^{* * *} \\
(0.004)\end{array}$ & $\begin{array}{c}0.019 * * * \\
(0.005)\end{array}$ & $\begin{array}{c}-0.021^{* * *} \\
(0.004)\end{array}$ & $\begin{array}{c}-0.019 * * * \\
(0.005)\end{array}$ & $\begin{array}{l}-0.001 \\
(0.001)\end{array}$ & $\begin{array}{l}-0.000 \\
(0.001)\end{array}$ \\
\hline Married*Children*Fall & $\begin{array}{c}0.012^{* * *} \\
(0.004)\end{array}$ & $\begin{array}{c}0.007 \\
(0.005)\end{array}$ & $\begin{array}{c}-0.011^{* * *} \\
(0.004)\end{array}$ & $\begin{array}{l}-0.006 \\
(0.004)\end{array}$ & $\begin{array}{l}-0.001 \\
(0.001)\end{array}$ & $\begin{array}{l}-0.001 \\
(0.001)\end{array}$ \\
\hline Female*Married*Children*Spring & $\begin{array}{c}-0.011^{* *} \\
(0.005)\end{array}$ & $\begin{array}{l}-0.008 \\
(0.006)\end{array}$ & $\begin{array}{c}0.011^{* *} \\
(0.005)\end{array}$ & $\begin{array}{c}0.008 \\
(0.005)\end{array}$ & $\begin{array}{l}-0.000 \\
(0.002)\end{array}$ & $\begin{array}{l}-0.000 \\
(0.002)\end{array}$ \\
\hline Female*Married ${ }^{*}$ Children*Summer & $\begin{array}{l}-0.007 \\
(0.005)\end{array}$ & $\begin{array}{l}-0.002 \\
(0.006)\end{array}$ & $\begin{array}{c}0.006 \\
(0.005)\end{array}$ & $\begin{array}{c}0.002 \\
(0.006)\end{array}$ & $\begin{array}{c}0.001 \\
(0.002)\end{array}$ & $\begin{array}{c}0.000 \\
(0.002)\end{array}$ \\
\hline Female*Married*Children*Fall & $\begin{array}{l}0.008^{*} \\
(0.005)\end{array}$ & $\begin{array}{c}0.016^{* * *} \\
(0.006)\end{array}$ & $\begin{array}{c}-0.010 * * \\
(0.005)\end{array}$ & $\begin{array}{c}-0.018 * * * \\
(0.006)\end{array}$ & $\begin{array}{c}0.002 \\
(0.002)\end{array}$ & $\begin{array}{c}0.002 \\
(0.002)\end{array}$ \\
\hline Constant & $\begin{array}{c}0.957^{* * *} \\
(0.001)\end{array}$ & $\begin{array}{c}0.968 * * * \\
(0.001)\end{array}$ & $\begin{array}{c}0.039 * * * \\
(0.001)\end{array}$ & $\begin{array}{c}0.029 * * * \\
(0.001)\end{array}$ & $\begin{array}{c}0.004^{* * *} \\
(0.000)\end{array}$ & $\begin{array}{c}0.002^{* * *} \\
(0.000)\end{array}$ \\
\hline Observations & $2,968,942$ & $2,968,942$ & $2,968,942$ & $2,968,942$ & $2,968,942$ & $2,968,942$ \\
\hline R-squared & 0.023 & 0.033 & 0.023 & 0.033 & 0.002 & 0.002 \\
\hline
\end{tabular}

Robust standard errors in parentheses

*** $p<0.01, * * p<0.05, * p<0.1$ 